Año: 2018

DOI: https://doi.org/10.51743/cih.71

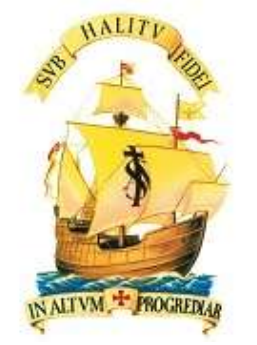

(c) $\underset{\mathrm{EY}}{(\text { ) }}$ (9)

\title{
LA VIDA RELIGIOSA EN LOS ESCRITOS DE SANTO TOMÁS DE VILLANUEVA
}

\author{
RELIGIOUS LIFE IN THE WRITINGS OF SAINT THOMAS DE \\ VILLANUEVA
}

\author{
MigUel ÁNGEL ORCASITAS, OSA
}

\begin{abstract}
Resumen
Sto. Tomás de Villanueva fue religioso agustino antes de ser nombrado arzobispo de Valencia, pero mantuvo siempre un estilo de vida acorde a su condición de religioso. En sus predicaciones hay muchas referencias a la vida religiosa, que centran la atención de este estudio. Como otros santos padres en diferentes épocas históricas, Sto. Tomás de Villanueva es, sin duda, uno de los pilares de la reforma de la Iglesia en España y de la defensa de la ortodoxia y de la vida religiosa. La seguridad de su enseñanza, fundada en la Biblia, acorde siempre con la doctrina de la Iglesia, hace que el santo arzobispo de Valencia tenga un lugar destacado en la historia de la Iglesia y que ocupe un puesto eminente entre los defensores de su doctrina y de su moral. Fue doctor no innovando, sino sosteniendo y defendiendo la doctrina frente a la desintegración que experimentaba la vida religiosa en Europa, como fruto de los ataques y principios de los reformadores protestantes y de su propia relajación interna. Esta seguridad de su magisterio resulta evidente en la defensa del valor de la vida consagrada y de los principios evangélicos y bíblicos en que se inspira, en total sintonía con lo proclamado años después por el concilio de Trento.
\end{abstract}

Palabras clave: Santo Tomás de Villanueva, agustinos, reforma de la Iglesia, arzobispo de Valencia, vida consagrada. 


\begin{abstract}
Sto. Tomás de Villanueva was an Augustinian religious before being appointed Archbishop of Valencia, but he always maintained a lifestyle according to his religious status. In his preaching there are many references to religious life, which are the focus of this study. Like other holy fathers in different historical times, Sto. Tomás de Villanueva is, without a doubt, one of the pillars of the reform of the Church in Spain and of the defense of orthodoxy and religious life. The security of his teaching, founded on the Bible, always in accordance with the doctrine of the Church, makes the holy archbishop of Valencia have a prominent place in the history of the Church and occupy an eminent position among the defenders of his doctrine and of their morals. He was a doctor, not innovating, but supporting and defending the doctrine against the disintegration that religious life was experiencing in Europe, as a result of the attacks and principles of the Protestant reformers and of his own internal relaxation. This security of his magisterium is evident in the defense of the value of consecrated life and of the evangelical and biblical principles in which he is inspired, in total harmony with
\end{abstract}

Keywords: Saint Thomas of Villanueva, Augustinians, Church reform, Archbishop of Valencia, consecrated life

\title{
I. INTRODUCCIÓN. El AGUSTINO TOMÁS DE VILLANUEVA:
}

$\mathrm{L}^{2}$ a figura de Sto. Tomás de Villanueva como religioso ha sido objeto de atención por parte de todos sus biógrafos. Partiendo de la educación religiosa recibida en casa y su contacto con la orden franciscana, es conocida su vida como estudiante y profesor en Alcalá y su opción de ingresar en el convento de San Agustín de Salamanca, donde profesó el 25 de noviembre de $1517^{1}$.

A pesar de formar parte el convento de una provincia reformada, optó por esta orden, a juicio de su biógrafo Miguel Salón, por considerarla en el justo medio que mejor se adaptaba a sus posibilidades, pues "ni de pesada o rigurosa excedía sus fuerzas, ni de menos de libre o floja entibiara su devoción." ${ }^{2}$ Ordenado sacerdote en 1518 será nombrado prior de Salamanca al año siguiente, lo que hace suponer el prestigio y aceptación que gozaba en la provincia.

\footnotetext{
${ }^{1}$ Para una síntesis sobre su formación en Alcalá y una semblanza como religioso agustino, formador y superior, ver Arturo LLIN CHÁFER, "La espiritualidad sacerdotal en Santo Tomás de Villanueva", en Colegio Mayor Seminario de la Presentación B.V. María en el templo y Santo Tomás de Villanueva. Conmemoración del 450 aniversario de la muerte de Santo Tomás de Villanueva, Valencia, Edicep, 2008, 59 (religioso agustino pp. 54-70). Afirma que, como prior en diversos conventos, "forjó prácticamente una escuela de formación sacerdotal". Ver también Arturo LLIN CHAFER, Santo Tomás de Villanueva. Una vida al servicio de la Iglesia, Madrid, Editorial Agustiniana, 1998, 25-50. Argimiro TURRADO, OSA, Santo Tomás de Villanueva, maestro de teología y espiritualidad agustinianas, Madrid, Revista Agustiniana, 1995, 15-26, 57-69, 75-85. Antonio CAÑIZARES, Santo Tomás de Villanueva. Testigo de la predicación española del siglo XVI, Madrid, ISP, 1973, 13-54. Javier CAMPOS Y FERNÁNDEZ DE SEVILLA, OSA, Santo Tomás de Villanueva, El Escorial, Ediciones Escurialenses, ${ }^{2} 2008$, 49-124. Juan José VALLEJO PENEDO, OSA, "Santo Tomás de Villanueva, agustino", en Isaac GONZÁLEZ MARCOS, OSA (ed.), Santo Tomás de Villanueva. 450 aniversario de su muerte. VIII Jornadas agustinianas, 12-13 marzo 2005, Madrid, Centro Teológico San Agustín, 2005, 67-93.

${ }^{2}$ Libro de los grandes y singularísimos ejemplos que dejó de sí en todo género de santidad y virtud el Ilustrísimo y reverendísimo Sr. D. Fr. Thomás de Villanueva, Valencia 1620, 17.
} 
Desempeñó el priorato en el convento de Salamanca en dos periodos capitulares. Posteriormente fue prior, otros dos periodos, de la comunidad de Burgos y uno más en la de Valladolid. Nombrado visitador general, presidió varios capítulos provinciales y fue elegido como prior provincial, desempeñando el cargo dos veces, en las provincias de Andalucía y de Castilla. En su condición de superior provincial se preocupó por la vida litúrgica de las comunidades, dando importancia al culto y enfatizando la importancia de la eucaristía como actividad central de la vida religiosa. Se preocupó por el modo de rezar el oficio divino en comunidad y por las actividades de los religiosos.

Aunque él mismo no fue a América, envió misioneros de la orden, a partir de la segunda barcada de misioneros. ${ }^{3}$ Veía un futuro para la Iglesia en los nuevos territorios. Decía:

"Tengo una fuerte sospecha de que el cristianismo está huyendo de nosotros y está emigrando a las Indias. A la Iglesia por acá se la mira con desprecio y se está contaminando."

Su formación académica pudo tener relevancia particular para transmitir el amor por el estudio a los religiosos más observantes, tentados por el abandono de las letras y de la dedicación intelectual. El estudio fue para Sto. Tomás requisito indispensable para un ministerio más fecundo y lograr un mayor influjo en la sociedad ${ }^{5}$. Estudio centrado, en primer lugar, en la Biblia, como se practicaba en la universidad de Alcalá en que estudió y enseñó y en los conventos agustinos en que vivió. ${ }^{6}$

Fuera del ámbito de la provincia, gozó del aprecio del prior general, Jerónimo Seripando, que le consideraba santo y ejemplar. El general contó con él en

\footnotetext{
${ }^{3}$ La dimensión misionera estuvo muy presente en la orden en España. Falló el intento de una primera expedición a América en 1528, haciéndolo por primera vez en 1533. Desde ese año hasta 1600 fueron a América 57 expediciones, con un total de 724 misioneros agustinos.

${ }^{4}$ STO. TOMÁS DE VILLANUEVA, Obras completas, Edición bilingüe promovida por la Federación Agustiniana Española (F.A.E.). Estudio preliminar, edición crítica e índices: Laureano MANRIQUE, OSA; traducción: Isidro ALVAREZ, OSA; aparato crítico: José Manuel GUIRAU, OSA, 10 volúmenes (11 tomos), Madrid, Biblioteca de autores cristianos (BAC), años 2010-2015. (En adelante $O C$ ). La cita corresponde a: Conción 131,2, Lunes IV semana de Cuaresma, $O C$, vol. III, pag. 411.

Estos son los años de edición de los diferentes volúmenes de las Obras completas: vol. I (2010); vol. II y III (2011); vol. IV-VI (2012); vol. VII-VIII/1 (2013); vol. VIII/2-IX (2014; vol. X (2015).

${ }^{5}$ Cfr. Luis ALVAREZ GUTIÉRREZ, "Santo Tomás de Villanueva, mentor, impulsor y patrono de los estudios en la orden”, en: Isaac GONZÁLEZ MARCOS, OSA (ed.), Santo Tomás de Villanueva..., 99.

${ }^{6}$ Cfr. Antonio CAÑIZARES, Sto. Tomás de Villanueva, testigo..., 33.
} 
algunos asuntos y le nombró en 1543 único representante español en la comisión encargada de revisar las constituciones. ${ }^{7}$

A raíz de su nombramiento como arzobispo, Fr. Tomás agradeció la carta de felicitación del prior general, al que manifiesta su añoranza por la vida del convento. ${ }^{8}$ Amaba, en efecto, su vocación religiosa, habiendo vestido el hábito agustino, antes de su designación como arzobispo, por espacio de 28 años.

La aceptación del episcopado fue para él tan dura como lo fue para su padre y maestro San Agustín. Vivió un auténtico proceso de conversión al aceptar servir a la Iglesia, abandonando la vida de comunidad. Será obispo por otros diez años largos, en los que llegó a ser modelo de pastor y padre de los pobres.

Como dijo Francisco de Quevedo, sentía profundo rechazo a la promoción ante los cargos y, muy particularmente, el episcopado:

"Fue amante tan amartelado de la observancia y retiramiento de su religión y su celda, que desdeñaba, no sólo con desprecio sino con asco, las dignidades y cargos" $"$.

Siendo arzobispo de Valencia, a partir de 1544, continuó viviendo como fraile, practicando una vida austera de extrema pobreza. Siguió vistiendo el hábito, y éste roto y remendado. ${ }^{10}$ Se sentía religioso agustino, como recuerda al pueblo en bastantes ocasiones, sobre todo hablando a religiosos o refiriéndose a ellos en su ministerio pastoral. Por ejemplo:

"nosotros, que hemos hecho profesión de vida espiritual, ¡con qué esmero, con qué atención debemos preocuparnos de ser lo que hemos prometido, hasta alcanzar la belleza de costumbres propuesta!

Porque tampoco en el monasterio hacemos otra cosa: estamos alejados de toda clase de preocupaciones y negocios, no nos apremia ni el cuidado de los hijos, ni la servidumbre de la casa, ni los asuntos de la familia. No sembramos, ni cosechamos; no estamos en la milicia, ni en la fábrica; vivimos libres de todo cargo y actividad exterior, para que nos ocupemos sólo de nosotros.

\footnotetext{
${ }^{7}$ Esa misma valoración positiva reflejan las actas del proceso de canonización, sobre todo en las deposiciones de religiosos y de quienes le conocieron antes de su ordenación episcopal. Sus hermanos de hábito resaltan el espíritu de oración y coinciden en subrayar la aceptación por obediencia del arzobispado de Valencia. Cfr. Carta del prior provincial, Francisco de Nieva, a Tomás de Villanueva, fechada en Toledo el 2 de agosto de 1544, imponiéndole por obediencia la aceptación del arzobispado de Valencia, en $O C$, X, 404-405. Para el proceso de canonización, cfr. Santo Tomás de Villanueva. Reliquias y proceso de beatificación. Transcripción y notas Laureano MANRIQUE, OSA, San Lorenzo del Escorial, IEIHA, 2014. Laureano Manrique ha transcrito también en dos volúmenes manuscritos las actas en latín del proceso de canonización que se conserva en Roma, en el que se recogen todos los testimonios, ordenados por virtudes.

${ }^{8}$ Cfr. Epistolario y testamento 7, Carta al general OSA Girolamo Seripando, Valencia, 24 enero $1545, O C, \mathrm{X}, 323$.

${ }^{9}$ Francisco de QUEVEDO, Vida de Santo Tomás de Villanueva, Guadarrama, Ed. Revista Agustiniana, 2005, 53

${ }^{10}$ Francisco de QUEVEDO, Vida..., 59.
} 
[...] ¡Qué buenísima suerte y condición privilegiada la nuestra! Por dedicarnos a cultivar la heredad de nuestro corazón, recibimos una recompensa, se nos da un salario. ¿Qué vamos a decir en el juicio? ¿Qué excusa tendremos si encuentran que somos carnales e incultos? La preocupación podrá de algún modo ser una excusa para las vírgenes seglares, pero a nosotros, ¿qué otro remedio nos queda más que callar la boca ante el juez, como aquel siervo inicuo del Evangelio? (Mt 22,13)."11

Conocía muy bien a S. Agustín, a quien menciona con frecuencia exponiendo su pensamiento. En treinta y ocho ocasiones le cita invocándole como "nuestro Padre". En las Obras completas se recogen cinco sermones en la fiesta de S. Agustín, a quien considera fundador "no de una que otra familia religiosa, sino de casi todas", porque se inspiran en él y profesan su regla. ${ }^{12}$ Resalta en Agustín cuatro carismas fundamentales:

"Fue, en efecto, un hombre muy santo en el cumplimiento de los preceptos, doctísimo por su conocimiento de las Escrituras, ilustre por su magisterio y eminente en la vida religiosa." 13

Sto. Tomás dejó huella de la formación agustiniana en la fundación del colegio de la Presentación. En sus constituciones pueden verse vestigios de la regla de S. Agustín. El nombre mismo del colegio está vinculado a la experiencia de Sto. Tomás como religioso, pues le puso bajo esta advocación mariana porque el día de la Presentación recibió el hábito de la orden. Por eso,

"en memoria de este beneficio dediqué este colegio a la Santa Virgen. Por esto determinamos y mandamos que en el dicho día de la Presentación, en la capilla de dicho Colegio, se celebre una fiesta solemne de la misma Virgen."14

Como lugar de sepultura eligió el convento agustino del Socós pues

"Ya que este empleo de arzobispo [...] me ha embarazado habitar con mis hermanos los religiosos en vida, no me lo impida después de mi muerte [...] por ser justo que vuelva esta oveja al rebaño de S. Agustín, de donde salió."15 Fue amortajado con el hábito agustino.

\footnotetext{
${ }^{11}$ Conción 312,5, Santa Dorotea, OC, VIII/1, 321.

${ }_{12}^{12}$ Conción 293,7, S. Agustín, nuestro Padre, OC, VIII/1, 33.

${ }_{13}^{13}$ Conción 294,3, S. Agustín, nuestro Padre, OC, VIII/1, 55.

${ }^{14}$ Constituciones del Colegio Mayor de la B. V. María "de Templo", OC, X, 383.

${ }^{15} \mathrm{Cfr}$. Testamento de Tomás de Villanueva, otorgado el 3 de setiembre de 1555 ante el notario Juan Alemany, en $O C, \mathrm{X}, 349$. Ver: José Vicente ORTI Y MAYOR, Vida, virtudes, milagros y festivos cultos de Santo Thomás de Villanueva, Arzobispo de Valencia, de la orden de San
} 


\section{LA VIDA RELIGIOSA EN LAS CONCIONES DE STO. TOMÁS DE VILLANUEVA}

Objeto principal de este trabajo no es la vida de Sto. Tomás como religioso, muy estudiada por sus biógrafos. Tampoco su visión del ideal monástico específicamente agustiniano, sobre el que escribió en su día Argimiro Turrado. Nos interesa la consideración que otorga Sto. Tomás a la vida consagrada en su obra, tal como aparece en la versión castellana de las Obras completas publicadas entre los años 2010 y 2015. Estará, por tanto, centrado en las palabras mismas de Sto. Tomás.

A lo largo de todos sus sermones hay frecuentes referencias a la vida religiosa, en algún caso con bastante extensión, aunque sólo alguno de ellos fue predicado específicamente a religiosos. En concreto hay dos conciones dirigidas a personas consagradas (nn. 41 y 279), quizás pronunciadas antes de ser designado arzobispo de Valencia. Trata el tema con bastante amplitud en alguna otra y les dedica mucha extensión en otras cinco. Entre sus Obras consta también una Plática y aviso al religioso que toma hábito ${ }^{16}$, escrita en castellano, directamente centrada en la vida religiosa y, entre los últimos fragmentos de sus Obras, existe un párrafo titulado Para el velo de las monjas. ${ }^{17} \mathrm{El}$ alto número de referencias sobre la vida religiosa permitiría publicar una nutrida antología de textos.

En un momento en que el protestantismo negaba el valor de la vida religiosa y denigraba los votos, Tomás de Villanueva defiende su vigencia en la Iglesia y la sociedad desde un planteamiento rigurosamente ortodoxo. Es, sin duda, uno de los pilares en España de la reforma de la Iglesia y de la vida religiosa.

De la lectura de las conciones se deduce que raramente figuraban religiosos o religiosas entre sus oyentes. El propio arzobispo entiende que el lugar de los religiosos y, sobre todo, de las religiosas, entonces mayoritariamente de clausura, es el convento, por lo que critica la salida injustificada del mismo. Elogia la clausura, como hará poco después también el concilio de Trento. ${ }^{18}$

Como obispo fue amante de la vida religiosa. La ensalza en sus sermones, aunque también subraya sus fallos y carencias, invitando a la reflexión y renovación, a pesar de haber conocido y experimentado personalmente una vida

\footnotetext{
Agustín, Valencia 1731, citado por F. Javier CAMPOS FERNÁNDEZ DE SEVILLA, OSA, Sto. Tomás de Villanueva. Universitario, agustino y arzobispo en la España del s. XVI, San Lorenzo del Escorial, EDES, ${ }^{2} 2008,250$. Cita también en Introducción, OC, I, pag. XCIX.

${ }^{16} O C, \mathrm{X}, 211-222$.

${ }^{17} \mathrm{OC}$, IX, 554.

${ }^{18} \mathrm{El}$ decreto sobre los religiosos y las monjas fue aprobado por el concilio en la XXV Sesión, celebrada los días 3-4 diciembre 1563. Santo Tomás había fallecido en 1555.
} 
religiosa profundamente transformada gracias al impulso renovador generado por el cardenal Cisneros, bajo los Reyes Católicos.

$\mathrm{Su}$ aprecio de la vida religiosa no se limitaba a los agustinos, sino que valoraba todos los carismas presentes en la Iglesia. Predicando el día de S. Francisco decía:

“...los padres fundadores de órdenes religiosas, extendieron de modo admirable la ciudad de Dios y la hicieron crecer en toda clase de perfección y virtud, y en cantidad de personal. [...] No hay reino, no hay país en que Francisco no tenga un monasterio, aun entre los turcos y los moros, por clara disposición divina. Cada santo fundador ejerció a su estilo el trabajo. San Benito escogió la clausura y quiso que sus frailes alabaran a Dios enclaustrados. [...] Llegó Agustín y situó a sus monjes en el eremo, para que le siguieran por caminos distintos y en ramificaciones diversas, como ángeles en la carne y segregados del mundo, dándoles por enseña un corazón, para que entendiesen que debían poner todo su esfuerzo y habilidad en perfeccionar el corazón. [...] A la hora de la tarde llegó santo Domingo: rasgando las tinieblas de los pecadores, decidió iluminar la Iglesia de Dios y funda una Orden exclusivamente para la instrucción. [...] Por su parte, Francisco, para hacer frente a los vicios y a la vanidad del mundo, creó una Orden austera, menospreciadora del siglo, de modo que sus frailes, sólo con verlos enseñaran ese menosprecio, que predicaran con el ejemplo; y quiso que fueran pobres, desprovistos de todo, a fin de que, cuando por necesidad apremiante piden limosna, ellos mismo la den mayor con su ejemplo." 19

A continuación describe con acierto e intuición las características de las principales órdenes y sus fundadores: Benito, Agustín, Domingo y Francisco:

"Benito eligió los pies de Cristo; Agustín, el corazón; Domingo, la lengua; Francisco, la cabeza llena de espinas.",20

La denuncia de incumplimientos de las normas y del modo aseglarado de vivir los eclesiásticos, tanto clérigos como religiosos, está presente en sus sermones. Como hicieron otros contemporáneos, se mostró crítico con los modos de vida de clérigos y religiosos:

"La segunda causa de que haya en el pueblo tantos vicios y tantos males, está en que los eclesiásticos, ya sean religiosos, ya clérigos, dicen y no hacen. Es ciertamente terrible que nosotros, que debemos ser entre el pueblo la luz que alumbre el camino de la salvación, seamos ocasión de pecado. Si los frailes y los clérigos fuésemos como debemos ser, ¡cómo nos respetarían y nos

\footnotetext{
${ }^{19}$ Conción 318,11-13, S. Francisco, OC, VIII/1, 437,439.

${ }^{20}$ Conción 318,13, S. Francisco, OC, VIII/1, 439.
} 
temerían los pecadores! Pero si yo, que soy monje, no hago otra cosa que visitar mujerzuelas y pasar el día entero charlando con ellas; [etc. ...] un mundano, ¿qué hará? De ahí se explica que la nación vaya cada día peor, y que al fin se hunda." 21

La raíz del comportamiento errático e impropio de algunos religiosos pudo ser una falsa motivación vocacional. Algo que puede darse en otras profesiones como la magistratura y en el sacerdocio, convirtiendo en Dios su estómago, es decir, orientándose por sus bajas apetencias y deseos materiales. Lo expresa al pueblo con particular crudeza:

“iAy, cuántos no serían clérigos, ni frailes, si no fuera por el pan! Esos tales no buscan a Cristo, sino su estómago. A ésos les dice Cristo: «Venís en mi busca para comer de mi pan; como di de comer hasta hartarse a mucha gente en el desierto, pensáis que mis rentas son muchas. Éstas son las que buscáis, no a mí».

De igual modo, ¡cuántos hay, entre el pueblo, que aspiran afanosamente a las magistraturas, a los altos tribunales, para vivir de ellos! Y eso no significa buscar la justicia, ni a Dios, sino el estómago. A éste lo tenéis entronizado como a un dios para vosotros, y por este dios queréis administrar justicia. Pero ése no es Dios. Dios es el fin último de todo y todo se debe hacer mirando al fin. Por lo mismo, si buscas a Dios con miras propias te haces dios de Dios, porque te haces fin de Dios.

Vas y preguntas a un sacerdote qué es lo que busca en la iglesia. Y él te responde: misas y sermones, porque ahora estoy necesitado. Y si no estuviera en necesidad, no se ocuparía ni de misas ni de sermones." ${ }^{22}$

Son ideas que repite en otras conciones, por ejemplo en el IV domingo de cuaresma:

“ ¡Cuántos hay que no serían eclesiásticos, frailes, si no fuese por tener de comer! Eso es buscar a Cristo por vuestro vientre. Me buscáis porque estáis saciados. Me buscáis porque os regalo, porque hay buenas rentas. ¡Cuántos hay que buscan la justicia, oficios, porque de allí vivirán! Eso es buscar a Dios por vuestro vientre, a vos, y a vuestro paladar, y a vuestro estómago."23

El mal ejemplo de frailes y clérigos hace que se desoriente el pueblo y no avance en su camino de perfección ${ }^{24}$.

${ }^{21}$ Conción 99,10, Martes II semana de cuaresma, OC, III, 13.

${ }^{22}$ Conción 127,6, Dom. IV Cuaresma, OC, III, 375.

${ }^{23}$ Conción 6 [127] [Inédito, en castellano], Dom. IV Cuaresma, OC, IX, 448.

${ }^{24}$ Cfr., por ejemplo, Conción 2 [90], [En castellano. Inédito] 10, Martes Sem. II Cuaresma, $O C, \mathrm{IX}, 423$. 
Fustiga a los que incumpliendo su regla de vida y malviviendo como religiosos se dedican a denigrar el estilo de vida que han abrazado:

"Son de ver en nuestros días muchísimos monjes desacreditando, con su aspecto sombrío, con su rostro pálido, una tierra deseable. «Esta religión — dicen - se traga a sus habitantes; esta vida es áspera, y reseca, y estéril; no hay quien la pueda soportar. Hay allí monstruos gigantescos, trabajos insufribles, obediencia sin tregua, prolongadas vigilias, clausura perpetua, frugal comida, coro continuo, rigor constante, muchas fatigas, ningún consuelo, tristeza infinita. No entréis, no probéis, estos trabajos superan las fuerzas humanas, no podréis con ellos. Hemos descubierto no una religión que mana leche y miel, sino ajenjo y hiel». ¡Oh raza pérfida y malvada de seres humanos! Achacan su desidia y su pereza a la austeridad y esterilidad de la vida religiosa." 25

Critica también que "los frailes no paran en casa"26.

La profesión religiosa, por favor de Dios, libera al consagrado de los afanes del mundo para dedicarse íntegramente a Dios. Nunca darán suficientes gracias a Dios por este don. Pero ay del religioso que se desvía del propósito asumido. Merecen doble condenación:

"iQué agradecidos deben estar los religiosos a Dios por el favor que les ha hecho al liberarlos de todos los afanes del mundo, de modo que sus corazones, por una permanente rociada celestial, estén siempre preparados para acoger la palabra de Dios! Aunque pasaran la vida entera alabando a Dios por tanta benevolencia, no pagarían la deuda. Pero, por otro lado, jay del mal religioso, cuyo corazón, libre y capaz de producir frutos de buenas obras para Dios, germina espinas y las cultiva! A su alma no le bastará una simple condenación ni un solo infierno, sino que le esperan doblados. ${ }^{27}$

No basta con ser religioso, si no se vive en conformidad con la profesión abrazada:

"Recordad, hermanos, que sois operarios, que os han contratado para trabajar en la viña. El obrero que se pasa el día entero jugando y danzando, comiendo y bebiendo, y no da golpe en el trabajo, ¿qué salario va a recibir de su amo cuando llegue la noche, sino son azotes y palos? Obreros son su majestad el rey, el obispo, el religioso, la "dama" y todo hombre, quienesquiera que sean: que cada cual cumpla con su oficio y realice bien su trabajo. [...] El

\footnotetext{
${ }^{25}$ Conción 312,9-10, Sta. Dorotea, virgen y mártir, OC, VIII/1, 327,329.

${ }^{26}$ Conción 32, Dom. II Epifanía, OC, I, 503.

${ }^{27}$ Conción 49,10, Dom. de Sexagésima, OC, II, 147
} 
religioso tibio, que no ara ni siembra porque no ora ni alaba a Dios, ¿qué espera recibir?"28.

Denuncia la tibieza existente en muchas vírgenes consagradas por estar vacías de Cristo.

"En todas partes es dado escuchar en los claustros quejas deplorables sobre la abstinencia, la pobreza, el ayuno, las vigilias, la obediencia, la clausura, el rigor de la disciplina monástica, la austeridad de la vida regular: les parecen penosas las cumbres de la virtud porque ellas están vacías y desprovistas de la gracia celestial, pues la que esta grávida del Verbo de Dios, por decisión espontánea y no a la fuerza, esa camino aprisa hacia las alturas. ¿Por qué se les hace tan duro a estas, sino porque les falta la gracia? ¡Ay! Aquel sosiego y encanto del paraíso, lo consideran hoy una cárcel; y las delicias de la religión y los atractivos de la devoción se han trocado en amarguras y lamentos. Y hasta el espíritu de auténtica libertad es considerado como objeto de servidumbre., 29

El simple elenco de estas prácticas da a entender el nivel de exigencia que llevaba consigo tipo de vida religiosa conocido, vivido y predicando por Sto. Tomás. Penitencias y privaciones serán llevaderos y hasta gozosos con la gracia de Dios.

La perseverancia en el propio camino es imprescindible para alcanzar la meta. Sto. Tomás critica a los que cambian fácilmente de dirección:

“¡Cuántas veces engaña el diablo a los viajeros con prisas, induciéndoles a dejar el buen camino por el que marchan y pasarse al camino de otros! El que se dedica al coro, desea el púlpito; el que predica por los pueblos, quiere la paz del coro; el que está trabajando por el Señor en el servicio a los hermanos, suspira por el ocio de la oración, y el que se mantiene en ese ocio, desea el fruto de los que trabajan. Con lo que sucede que, al envidiarse unos a otros y desear uno lo que es tarea de otro, se cumple más imperfectamente el propio cometido. Gran engaño es ése, hermanos, y que, bajo pretexto de piedad, retarda mucho a los caminantes con prisas." 30

El religioso, como los Magos dirigiéndose al pesebre guiados por la estrella, deberían mostrar su diligencia, fervor y perseverancia para conocer a Jesús, guiados por la fe:

“¡Ah, queridísimos hermanos, ah si nosotros buscáramos así al Señor! [como los Magos], iSi con esa misma diligencia, fervor y perseverancia in-

\footnotetext{
${ }^{28}$ Conción 42.2, Dom. Septuagésima, OC, II, 29.

${ }^{29}$ Conción 279,10, Visitación B Virgen María, $O C$, VII, 333

${ }^{30}$ Conción 329, 7, San Lesmes, OC, VIII/2-3, 77,79.
} 
tentáramos conocer a Jesús! ¡Qué grande es nuestra tibieza, qué grande nuestra indolencia, cuánta nuestra despreocupación! Si hacemos propósitos de buscar a Dios, al mínimo obstáculo desistimos, al momento lo dejamos; apenas si nos mantenemos un día en nuestro empeño. [...] Fíjate en el monje, mira al sacerdote, al obispo: toca, y notarás que allí hay vacío, carencia de fervor, ausencia de celo, falta de amor. Todo está lleno de vanidad. [...] Así pues, busquemos también nosotros a Jesús, no en el establo, sino en el cielo; no en el regazo de la madre, sino en el seno del Padre. Busquémoslo con la luz de la estrella, quiero decir, de la fe. Es ella la que nos guía en este lugar tenebroso y oscuro: sigámosla, no apartemos los ojos de ella, ella nos mostrará al rey en su esplendor. Tened cuidado con las enseñanzas desviadas, evitad las lecturas perniciosas, que su palabra se extiende como el cáncer. Evitad la compañía de los malos de estos tiempos." ${ }^{31}$

Su visión de la vida religiosa es acorde al contexto reformista que experimentó y propuso. Propugna la vuelta a las fuentes, Evangelio y regla, con rigor y pureza. Pureza del corazón. Amor al silencio, a la oración y contemplación, al estudio y a la caridad fraterna, ${ }^{32}$ porque el estudio es nada sin el aceite de la caridad:

"¿Cómo te extrañas de que la virginidad sea excluida, cuando ni la fe, ni el conocimiento, ni la enseñanza, ni la profecía, ni la limosna, ni el mismo martirio son gratos a Dios si falta el aceite de la caridad? [...] Pasamos el día y la noche dedicados a la sabiduría, nos entregamos incansables a la erudición y a los libros, y lo último de que nos ocupamos es del aceite de la piedad. [...] Hacedme caso, amantes de la sabiduría divina: Si queréis brillar, ungíos antes: que el aceite de la voluntad sostiene y aviva la lámpara del entendimiento. No tengáis descuidada la alcuza de la voluntad, si queréis calentar el horno de la sabiduría." 33

\section{CARACTERÍSTICAS DE SUS CONCIONES Y EXIGENCIAS DE LA PREDICACIÓN}

No existe una cronología cierta de sus sermones. Sabemos que predicó mucho antes de ser nombrado obispo, pero no resulta fácil determinar qué conciones corresponden a ese periodo entre las publicadas. Sería interesante, para cotejar su contenido con otras fuentes y autores contemporáneos. ${ }^{34}$

\footnotetext{
${ }^{31}$ Conción 244,6, Epifanía, OC, VI, 363,365.

${ }^{32} \mathrm{Cfr}$. Argimiro TURRADO, Sto. Tomás de Villanueva. Maestro de teología y espiritualidad agustinianas, Madrid, Ed. Revista Agustiniana, 1995, 60-69.

${ }^{33}$ Conción 311,5, Sta. Dorotea, OC, VIII/1, 297.

${ }^{34}$ Antonio CAÑIZARES ofrece alguna aproximación sobre lugares, tiempo y destinatarios de los sermones, basándose en su contenido o en circunstancias citadas en los mismos: cfr. Santo
} 
Por su longitud y contenido, las conciones superan con frecuencia lo que pudo ser un sermón. Algunas de ellas son auténticos tratados, de una duración que había de sobrepasar ampliamente el tiempo razonable de un sermón.

Atendiendo al lenguaje, toda su obra está plagada de citas bíblicas. La Sagrada Escritura constituía la fuente principal de inspiración, como caracterizó la renovación de la predicación de su época. En el uso tan frecuente de la Biblia demuestra la formación recibida en Alcalá y vivida en los conventos agustinos. $^{35}$

Tiene un dominio extraordinario de la Biblia. Maneja con soltura todos sus libros, tanto del Antiguo como del Nuevo Testamento. Toda su predicación se fundamenta y descansa en la Palabra de Dios. Una constante en sus conciones es la confirmación de cuanto afirma, paso a paso, con citas bíblicas. Resulta evidente que ha estudiado e interiorizado a fondo la Escritura y que tiene la Biblia en la cabeza y en el corazón. ${ }^{36}$ En eso puede compararse a su padre San Agustín, que incorporó la Biblia a la estructura de su pensamiento.

A pesar de su amor por la Biblia y el continuo uso que hace de ella citándola, reconoce que las buenas obras pueden ayudar más que la lectura de la Biblia:

"muchas veces sucede que se encuentra más luz y mejor conocimiento de Dios en el ejercicio de las buenas obras que en el estudio de las Sagradas Escrituras. [...] Parte, pues, y reparte tu pan a los pobres, y el Señor partirá para ti su pan, es decir, su luz.",37

Además de citas bíblicas, recurre también al testimonio de Santos Padres (sobre todo, demuestra conocer bien a San Agustín), e incluso a autores tanto cristianos como profanos.

A pesar de las continuas digresiones para introducir las citas bíblicas, su discurso es normalmente fluido y muy adaptado a los oyentes. ${ }^{38}$ Ofrece comparaciones de fácil comprensión para el pueblo, tomadas, con frecuencia, de la vida ordinaria o del trabajo en el campo. Por otra parte, es muy sistemático en sus exposiciones. Clasifica y ordena todo lo que va a decir, favoreciendo con ello la comprensión y gradación de sus afirmaciones.

Tomás de Villanueva..., 116-119.

${ }^{35}$ Cfr. Antonio CAÑIZARES, Santo Tomás de Villanueva..., 98, 33. Sobre el uso de la Biblia, cfr. Arturo LLIN CHAFER, Santo Tomás de Villanueva. Una vida al servicio de la Iglesia, Madrid, Ed. Revista Agustiniana, 1998, 104-107.

${ }^{36}$ Cfr. Antonio CAÑIZARES, Santo Tomás de Villanueva ..., 122, 200.

${ }^{37}$ Conción 164,7, Lunes de Pascua, OC, IV, 93, 95.

${ }^{38}$ La magnífica traducción al español de Isidro Álvarez, OSA, contribuye a percibir esa sensación de fluidez. 
Es evidente que Sto. Tomás no improvisa. Entra al fondo de los temas, en conformidad con la teología y espiritualidad de la época. Se percibe que sus discursos están minuciosamente preparados. Las ideas están muy ordenadas, frecuentemente numeradas y expuestas con gran sentido didáctico. En el proceso de beatificación testificó el sacerdote Antonio Juan Andreu, que ocho días antes de predicar un sermón Tomás se retiraba y lo preparaba en un clima de intenso recogimiento, concentrándose exhaustivamente en la oración. ${ }^{39}$ Es notoria su formación académica y su experiencia como profesor en la claridad y orden de sus exposiciones.

Oración y estudio son los dos pilares de una buena preparación para la predicación. Hay que preparar los sermones y vivir dando buen ejemplo. Así lo exige del predicador:

"El collar que cae sobre el cuello del predicador ha de tener oro y perlas: oro, buena teología, caridad, doctrina santa, que no suba aquí sin estudiar; ore, que beba bien los libros, etc. Más perlas: que tenga dos horas de oración, que ayune, castidad, templanza en todo, sin actos malos, que dé buen ejemplo, humildad. Éstas son las perlas del predicador. ¿Hallaríais uno de tantas perlas? ¡Ah, tarde se hallará tal predicador!”40

Del mismo modo que él preparaba concienzudamente los sermones, pedía al predicador hacer lo mismo:

"No subas al púlpito, te lo ruego, sin antes hacer una seria y meditada lectura de libros. Debes también distinguirte por las gemas y demás piedras preciosas, por tus virtudes, como la castidad, la humildad, el celo por las almas, de manera que en todo aparezcas como modelo de buenas obras. Debes entregarte, como mínimo durante dos horas, a la contemplación silenciosa de los temas sagrados, pidiendo a Dios su asistencia." ${ }^{41}$

La falta de coherencia entre vida y doctrina, la inadaptación al auditorio y la escasa preparación de los predicadores motiva que crezcan más en la sociedad los vicios que las virtudes. Dicen y no hacen predicadores, eclesiásticos, gobernadores, rectores, funcionarios, etc. Explica luego cada una de estas categorías u oficios, empezando por los predicadores:

“... el predicador debe esforzarse en que todo lo que diga no sea tan sublime y elevado que se haga ininteligible para sus oyentes; ni tan vulgar

\footnotetext{
${ }^{39}$ Santo Tomás de Villanueva. Reliquias y proceso..., XXXIV.

${ }^{40}$ Conciones cuaresmales castellanas, OC, IX, 422.

${ }^{41}$ Conción 99,6, Martes II semana de Cuaresma, OC, III, 11. Sobre la preparación de los sermones, cfr. Antonio CAÑIZARES, Sto. Tomás de Villanueva..., 201.
} 
y sabido que les produzca hastío. [...] Hay también otra causa -y ésta aún es peor- de por qué los predicadores no obtienen frutos, a saber: porque los predicadores dicen, pero no cumplen. No viven de acuerdo a la moral que predican." 42

La adaptación a la capacidad de los oyentes es fundamental para la eficacia de la predicación. Es curiosa la diferencia de criterio según el tipo de oyentes y el contenido mismo del sermón. Cuando lo exija la defensa de la fe o la corrección de los pecados del pueblo el sermón debe reunir características especiales, para producir mayor impacto y lograr más fruto:

"Señale al sabio el camino, pues no conviene producir hastío por la exposición y la dilación. Sea, pues, para los sabios el sermón breve y sencillo, en cambio para el pueblo sea largo, pero no elocuente, ni difícil, ni controvertido, sino expositivo y prolongado. Mas cuando se toque a rebato y se trate de la defensa de la fe contra los herejes, entonces el sermón será largo pero conciso, elocuente, ingenioso, juicioso, elegante, adornado, eficaz, poderoso y fuerte. Asimismo, cuando el pueblo deba ser corregido de sus pecados, entonces resuene la trompeta con más fuerza." 43

Muy presente el infierno y el diablo en su predicación, por los que justifica la necesidad de hacer el bien. Es muy exigente en la moral de los religiosos, monjes y eclesiásticos.

\section{CRÍTICAS A LA IGLESIA Y SOCIEDAD DE SU TIEMPO}

Sto. Tomás tiene una visión idealizada y parcial del pasado de la Iglesia, sobre todo porque establece como término de comparación figuras concretas y eminentes. Cita a Santos Padres, como Agustín, Jerónimo o Ambrosio, y a fundadores de órdenes religiosas como Benito, Francisco, Bernardo o Domingo, para atribuir al pueblo cristiano contemporáneo de estas figuras una santidad frente a la cual siente bochorno, por no resistir la comparación. Confrontados con ellos se ve como hormigas y langostas.

Contemplando la imagen de Juan Bautista ve en él un modelo acabado de vida consagrada:

"Compárese con él a un cartujo o a otro religioso cualquiera de vida austerísima: parecerá un iniciado y seglar. Compara hábito con hábito, comida con comida, rigor con rigor, lecho con lecho, casa con casa, devo-

\footnotetext{
${ }^{42}$ Conción 153,4-7, Dom. Ramos, OC, III, 779.

${ }^{43}$ Comentario de varios capítulos del libro de los Números, OC, X, 7.
} 
ción con devoción, y toda religión parecerá vida seglar. Que se miren los religiosos en él, y aprenderán pobreza, menosprecio del mundo, castidad, renuncia propia, abstinencia, oración, ayunos, penitencia; en fin, todo lo que importa a su estado lo hallarán en aquel perfectísimo dechado de religioso. [...] ¿Qué hace un religioso por las calles, en la plaza pública? ¿Qué en el cotilleo y en las visitas a mujeres? ¿Qué en los negocios y litigios? ¿Acaso fue llamado para esto a la vida religiosa? [...] Para la pureza y la contemplación son necesarios la soledad, el silencio y la paz; y esas condiciones no se dan en la plaza pública, sino en el monasterio. [...] La vida de Juan predica más que su lengua; [...] Juan era voz todo él $[\ldots]$ Su silencio y su soledad eran también voz. ${ }^{\$ 4}$

Juan Bautista es, a juicio de Sto. Tomás, el primer padre de la vida monástica, el primer fundador e ideólogo del celibato. Lamenta la lejanía de la vida religiosa del tiempo, por no encarnar la pureza del espíritu de Juan el Bautista.

"Juan fue el primer padre de la vida monástica, el primer fundador e ideólogo que enseñó a los hombres esta vida célibe, no en unas normas escritas, sino con el ejemplo de su conducta. [...] ¿Dónde están hoy, en la vida religiosa, aquella pureza, aquel candor, aquella santidad? ¿Dónde aquel fervor en la entrega, aquel rigor de la penitencia, aquella lozanía de la castidad? ¿Dónde aquella vida en soledad, aquella sobriedad, aquella moderación? ¿Dónde el desinterés por el vestido, el menosprecio del mundo, el celo por la justicia? ¡Ay de nosotros! Porque sólo llevamos el título vacío de la religión, la tonsura y el hábito: amantes del placer, delicados, soberbios, carnales, bulliciosos, paseantes, fríos, sin espíritu, sin devoción, negociantes, difamadores, correcalles. Nos hemos hecho unos más del pueblo, pero no seremos juzgados como el pueblo (Os 4,8-9). ${ }^{, 45}$

Idealiza la primera comunidad de Jerusalén, que inspiró el estilo de vida religiosa fundado y abrazado por S. Agustín:

"Me atrevo a decir que ni los igualan los que en nuestros días profesan la religión más austera. Pues aquellos vendían todas sus propiedades y ponían su importe a los pies de los apóstoles, y hacían vida comunitaria, prestando a los apóstoles una obediencia mayor y más estrecha que la de hoy a los superiores en el claustro. Tiempo después, a imitación de aquellos, perfeccionó san Agustín su fundación religiosa, considerando suficiente para la verdadera religión que sus frailes siguieran el plan y la regla de aquellos primitivos seglares. ${ }^{, 46}$

\footnotetext{
${ }^{44}$ Conción 325,15-16, S. Juan Bautista, OC, VIII/1, 605.

${ }^{45}$ Conción 323,8, S. Juan Bautista, OC, VIII/1, 573.

${ }^{46}$ Conción 183,9, Pentecostés, $O C$, IV, 451.
} 
La época apostólica hace suspirar al santo arzobispo por el fuego que encendió a la Iglesia. Hoy no hay chispa que reencienda el fuego que bajó sobre los apóstoles. Se ha apagado y se ha congelado el corazón de los hombres:

"Ya no hay calor de caridad en el mundo; aquel fuego que descendió de lo alto sobre los apóstoles (Hch 2,1ss) se ha apagado ya, se enfrió totalmente en el corazón de los hombres, se han congelado los corazones. No encontrarás, ni en los sacerdotes, ni en los religiosos, una chispita de calor espiritual. ${ }^{\circ 7}$

También le sirve la consideración de la iglesia martirial de los primeros siglos para establecer un contraste con la realidad de su tiempo. En esa época la religión brilló con todo su esplendor porque los cristianos afirmaban la fe entregando sangre y vida. Fue un tiempo de auténtico cristianismo, en contraste con las escasas exigencias y débil religiosidad del momento actual.

Es frecuente en la predicación de Sto. Tomás la crítica de los defectos de los prelados de su tiempo, sobre todo por su ausencia de las diócesis y por los intereses mundanos, delegando sus funciones pastorales en mercenarios.

"Todos [los prelados] están muy vigilantes sobre rentas y primicias: el cuidado de las ovejas, lo último. Pues entre los pastores, uno vive en el palacio de los príncipes, otro está liado en asuntos mundanos, otro se dedica al juego y a la caza, otro viaja a Roma para lograr más altas prebendas... y el redil de Cristo se deja en manos de mercenarios para que lo expolien, y lo despedacen, y lo dispersen: se encomienda a lobos el cuidado de las ovejas. ¿Qué ha de hacer el lobo hambriento más que despedazar, arrasar y matar? [...] El prelado de la Iglesia, que debía brillar en virtudes y en sabiduría, rebrilla por el oro y la seda. Y el ornato de las almas se ha trocado en culto al cuerpo. La Iglesia está gobernada por el favoritismo, no por el mérito, y para cuidar el rebaño se busca no a un sabio pastor, sino a un poderoso; no a un santo, sino a un rico, y a uno que oprima al pueblo de Dios con su poder, con preferencia a otro que lo edifique con su vida y lo instruya con su sabiduría." 48

Su crítica alcanza también a la vida religiosa. Su relajación y torpeza escandaliza a los sencillos, debido a que el hábito les confiere autoridad y prestigio. Más valiera a alguno de ellos no haber abrazado la vida religiosa antes de constituir un mal ejemplo para los fieles:

“... les hubiese sido mejor vivir en el siglo aplastados por la muela de las preocupaciones y urgidos por la ansiedad de los quehaceres, que, una vez to-

\footnotetext{
${ }^{47}$ Conción 322,8, S. Juan Bautista, OC, VIII/1, 543.

${ }^{48}$ Conción 229,12, Navidad, OC, VI, 43.
} 
mado el hábito religioso, vivir de modo que sirvan de escándalo, de relajación y de torpeza a los sencillos. Porque en el siglo su vida disoluta no se notaría tanto, no redundaría en daño de otros como cuando eso lo hacen los que por el hábito y la religión tienen autoridad y prestigio. [...] ¡Ay de los religiosos díscolos, cuyo ejemplo debía dar vida a los sencillos, y los echa a perder! ¿A qué se debe en la Iglesia de hoy tanta tibieza y tanta maldad? ¿Por qué tanta avaricia y ambición en todos, sino porque los mayores y los próceres de ella, que debían brillar en santidad, destacan por su maldad, y los jóvenes siguen los pasos de los mayores?"49

Denuncia la existencia de religiosos sin mentalidad religiosa. Algunos ingresan en la vida religiosa impelidos por la necesidad de su cuerpo, es decir, de su estómago. Su intención no es servir a Dios, sino a sí mismos. Es un toque de atención para no estar atentos a lo terreno más de lo necesario:

"Muchos se convierten a Dios, no tanto en la mente como en el cuerpo, lo cual sólo con dolorosos gemidos podemos contarlo: Tienen el hábito de la religión, pero no tienen la mentalidad religiosa. Muchos no tienen el espíritu de la religión; muchos, efectivamente, terminan convirtiéndose no tanto por la salud del alma, como por la necesidad del cuerpo; ésos no dan culto a Dios, sino a su estómago. De ellos decía el Apóstol: su Dios es el vientre (Flp 3,19). La intención de ésos no es servir dignamente a Dios, sino comer y beber bien, y vestir bien y que en el siglo les vaya todo bien; y como aman las cosas de la tierra, pierden las del cielo [...] Así pues, debemos estar atentos a no amar lo terreno y transitorio más de lo conveniente;",50

Algunos problemas del estado clerical derivan de la mala selección de los candidatos, ya que se destina a ese estado a los menos dotados o llenos de defectos:

"No se presenta al sacerdocio más que gente incapaz e inútil. Si entre los hijos hay uno que es medio lelo, indolente, cojo, tuerto, deforme, ése es para el Señor, [...] ¡Es desconcertante la tontuna de los hombres! ¿A quién puede uno entregar mejor su talento que al que se lo dio? ¿O en qué puede uno gastar todas sus energías y facultades mejor que en servicio del Creador?“51

No sólo critica a los religiosos sino también a otros estamentos sociales. A los religiosos negociantes porque abandonan claustro y coro para dedicarse a callejear por barrios y plazas. Algo que también hacen algunos sacerdotes, que desatienden su grey para acercarse a reyes y señores como consejeros o para

\footnotetext{
${ }^{49}$ Conción 339,6, S. Miguel, arcángel, OC, VIII/2-3, 281,283.

${ }^{50}$ Conción 363,4, Todos los santos, OC, VIII/2-3, 613.

${ }^{51}$ Conción 295,1, S. Agustín, nuestro Padre, OC, VIII/1, 65.
} 
presidir negociados públicos. O militares que viven en la ociosidad y el vicio, renunciando la defensa del pueblo. O matronas de la nobleza que abandonan la tarea de alimentar y cuidar a la familia. ${ }^{52}$

Acusa un enfriamiento general de la devoción en la Iglesia, añorando tiempos en que los cristianos vivieron cercanos a la hoguera celestial, calentándose en su amor. Ve su época alejada del fuego y la humanidad congelada.

"Hoy, hermanos, se ha enfriado aquella antigua devoción de los santos, el ardentísimo fervor y el fervorosísimo ardor. [...] ¿Dónde está aquel fervor de antes?, ¿dónde aquella piedad del pueblo?, ¿dónde el fuego ardiente de la caridad?, ¿dónde la infatigable alabanza y la acción de gracias?" [etc.]

Sto. Tomás suspira por la reforma de la Iglesia, necesaria incluso para resistir la presión de los turcos:

" $\mathrm{OOh}$ la reforma de la Iglesia, por largo tiempo deseada y nunca emprendida! ¡Oh, quién me diera verla con mis propios ojos antes de morir! Tened por seguro, hermanos, que mientras la Iglesia se mantenga en estas costumbres, es inútil la lucha contra los turcos: hay que luchar contra las costumbres antes que contra las huestes enemigas. En definitiva, enmendemos nuestra vida, adhirámonos a Dios y él luchará a nuestro favor., ${ }^{, 54}$

\section{EL HORIZONTE DE LA VIDA ETERNA}

Sto. Tomás vivió en una España donde ser católico no era una tendencia, sino una Verdad absoluta que no se podía discutir. ${ }^{55}$

Llin Cháfer afirma que Tomás de Villanueva tuvo un influjo reformista decisivo tanto dentro de la orden agustina como en la iglesia española del s. XVI, considerándole "uno de los artífices de la restauración católica" ${ }^{56}$, junto con otros destacados protagonistas en la Iglesia y en la orden.

La predicación de Sto. Tomás se mueve en las coordenadas de eternidad. La fe en la vida eterna, con el horizonte del premio y el castigo, está omnipresente en su predicación. No se trata de un fenómeno exclusivo suyo, sino de una vivencia generalizada en la sociedad cristiana de su tiempo, particularmente en la española. Se razona y respira en términos de eternidad, de la que la vida tempo-

\footnotetext{
${ }^{52}$ Conción 344,7, S. Nicolás de Bari, OC, VIII/2-3, 347,349.

${ }^{53}$ Conción 231,8, Navidad, OC, VI, 83,85.

${ }_{55}^{54}$ Conción 87,6, Jueves I semana de cuaresma, OC, II, 663.

${ }^{55}$ Cfr. Luis SUÁREZ FERNÁNDEZ, "El tiempo de San Alonso", en Revista Agustiniana 44 (2003) 31 .

${ }^{56}$ Arturo LLIN CHÁFER, Santo Tomás de Villanueva. Pastor de la Iglesia en tiempos recios, Guadarrama, Editorial Agustiniana, 2010, 27.
} 
ral es un tiempo de preparación. La vida del cristiano, y no digamos la del religioso, recibe iluminación desde la transcendencia. Sin ese presupuesto carecería de fundamento toda su predicación. Desde esa perspectiva, la realidad temporal, por larga que resulte, es un suspiro comparado con la vida eterna que nos espera. La vida presente es una jornada de obrero. "Y según haya sido el trabajo hecho, así será la paga" ${ }^{\text {"57 }}$. Dios ofrece paga de eternidad feliz como fruto de su amor inmenso hacia nosotros. Esa perspectiva es la fuerza que permite vivir dando preeminencia a los bienes eternos sobre los temporales, redimensionando el valor de éstos:

"yo no reconocería la miseria de la vida presente, sus carencias, su pequeñez, y pobreza, y cortedad, si no supiera que hay otra vida feliz. Porque, cuando comparo esta vida con aquella, me doy cuenta de lo deficitaria que es ésta. [...] ¿Por qué, en efecto, se tienen por viles estos bienes, sino porque se comparan con aquellos? Porque las cosas que se ven son transitorias, mas las que no se ven son eternas $(2 \mathrm{Cor} 4,18)$ ". ${ }^{58}$

En ese contexto adquiere todo su sentido la vocación religiosa. Con esa proyección transcendente tan remarcada no ha de sorprender que al referirse a la vida de los religiosos, pueda parecer incluso extremoso pues toda la vida del religioso debe transcurrir sub specie aeternitatis. No hay que olvidar que Sto. Tomás abrazó un estilo de vida religiosa reformada, en la que la disciplina interna, la obediencia, la pobreza y las penitencias constituían el entramado básico de la vida del religioso. Los votos son expresión de la negación de sí mismo que caracteriza al religioso que quiere seguir a Cristo. Citando a S. Bernardo exhorta a la religiosa a no dejarse vencer por el desaliento, la dureza del claustro o de los votos, invitándole a mirar al premio, que justifica los sacrificios que comporta la vida religiosa.

"Que nos mueva, pues, hermanos, a trabajar, la brevedad del trabajo, la magnitud del premio, la mirada del Señor [...] Pronto cesará la fatiga, y os llegará, $[\ldots]$ la recompensa eterna de la gloria" ${ }^{, 59}$.

Gracias a ese recuerdo anticipado del cielo es posible abrazar la vida rigurosa del ermitaño o de las monjas, con lo que significa de renuncias y sacrificios:

“¿Qué impulso «puebla hoy los monasterios» y consigue que débiles mujeres se encierren, como en un sepulcro, en los conventos de monjas, después

\footnotetext{
${ }^{57}$ Conción 41,2, Dom. Septuagésima, OC, II, 5.

${ }^{58}$ Conción 365,1, Todos los santos, OC, VIII 2/3, 635, 637.

${ }^{59}$ Conción 41,7, Dom. Septuagésima, OC, II, 19,21.
} 
de abandonar a sus padres y parientes, renunciando a maridos e hijos, a convivencias carnales y demás consuelos? Sólo el recuerdo de Jerusalén." ${ }^{60}$

Ironiza sobre los seglares que se burlan del religioso por sus renuncias y mortificaciones.

“... se ríen y lo tienen por loco. Es porque no saben los incontables frutos que va a recoger de aquella mortificación y de aquella recolección de virtudes y buenas obras; saben que las aflicciones tan breves y tan ligeras de la vida presente nos producen el eterno peso de una sublime e incomparable gloria (2Cor 4,17)." ${ }^{\circ 1}$

En una conción dedicada a Sta. Dorotea exhorta a las monjas a dedicar su vida a prepararse para la vida eterna, manteniendo sus lámparas encendidas y procurando que no les falte el aceite. El horizonte de la vida eterna es próximo, llegará más pronto de lo previsto:

"El tiempo llega volando (Dt 32,35), y la muerte, "a fuerza de remos y de vela", corre cuanto puede. ¡Oh deplorable ceguera la de los hombres! ¡Piensan que está lejos todo lo que les desagrada! Mirad que llega el esposo (Mt 25,6). Hacedme caso: ya casi casi está a la puerta. Salid a su encuentro, [...] ¿Por qué te da miedo, alma desdichada, de dejar la tienda de este cuerpo? Llega el esposo, ¿y no te mueves? Te está llamando, ¿y te niegas a salir? Sal, sal, y vete a su encentro con gozo, deja gustosa y voluntariamente esta casa de barro y en ruinas (Job 4,19), para entrar a vivir en aquella casa del cielo, no hecha por manos de hombres, perpetua $(2 \text { Cor } 5,1)^{, 62}$

Predicando el miércoles de ceniza decía que los monjes son un ejemplo ante la proximidad de la muerte y la fragilidad de la vida humana. ${ }^{63}$

La recompensa del cielo es pura gratuidad de Dios, y éste es un aspecto importante porque incluso el trabajo que ponemos para vivir en conformidad con el mandato del Señor es también fruto de la gracia. Pero al mismo tiempo, la recompensa es un acto de justicia, pues responde a una promesa de Dios:

"Aunque la retribución de los justos es un acto simplemente gratuito, sin embargo es un acto de justicia por razón de un pacto de Dios, [...] por mediar una promesa, porque es justo que Dios cumpla lo prometido. [...] Advierte, antes de nada, que cuando decimos que Dios obra en nosotros o por medio de

\footnotetext{
${ }^{60}$ Conción 52,6, Dom. Quincuagésima, OC, II, 209.

${ }^{61}$ Conción 51,23, Dom. Sexagésima, OC, II, 191.

${ }^{62}$ Conción 311,10, Sta. Dorotea, OC, VIII/1, 305,307.

${ }^{63}$ Cfr. Conción 63,4, Miércoles de ceniza, OC, II, 311.
} 
nosotros, $[\ldots]$ se hace algo porque Dios nos confiere la fuerza del obrar, y él mismo la mueve interiormente, la impulsa y la anima con sus santas inspiraciones, y esa fuerza opera por el poder de Dios y es virtuosa por él. Advierte también que, por el hecho de que nuestras obras sean dones de Dios, no por eso se las priva de la condición de meritorias. Pues quien utiliza correctamente un don recibido, y lo hace a honra del donante, se hace acreedor a recibir incluso otros nuevos sobre los ya recibidos. ${ }^{.64}$

Citando a S. Agustín en los soliloquios, afirma que el premio de la vida eterna es Dios mismo: "no sois tú una cosa y otra cosa tu recompensa, sino que tú mismo eres la recompensa inconmensurable."

El valor de los bienes temporales se relativiza a la luz de los eternos. La comparación entre la vida eterna y la temporal permite comprender el escaso valor de la vida presente:

"yo no reconocería la miseria de la vida presente, sus carencias, su pequeñez, y pobreza, y cortedad, si no supiera que hay otra vida feliz. Porque, cuando comparo esta vida con aquella, me doy cuenta de lo deficitaria que es ésta. Podrían razonablemente estimarse los bienes de la vida presente y amarse como grandes, si no se conocieran otros bienes eternos. ¿Por qué, en efecto, se tienen por viles estos bienes, sino porque se comparan con aquellos? [...] La pobreza y la rusticidad de la aldea y del caserío no se detectan sino comparándolos con la ciudad."

Aunque la fe en la vida eterna ilumina la realidad presente, no faltarán momentos de dificultad, superables teniendo en cuenta la perspectiva de la vida futura:

"Las penalidades, vistas por ojos perspicaces, son un momento comparadas con la eternidad del galardón: ahora bien, vistas en sí y aisladamente por ojos enfermos, parecen bastante más largas. No te pares a considerar, oh hombre, lo que estás pasando, piensa más bien en lo que estás esperando."${ }^{, 67}$

La vida religiosa es camino de salvación, incluso para los muy pecadores:

"¡Cuántos hombres hay que, viéndose abrumados de muchos pecados, se encierran en un monasterio, porque piensan que en el siglo no se salvarían! ¡Y terminan siendo santos!" ${ }^{\prime 68}$.

\footnotetext{
${ }^{64}$ Conción 45,24-25, Dom. Septuagésima, OC, II, 89.

${ }^{65}$ Conción 45,26, Dom. Septuagésima, OC, II, 89.

${ }^{66}$ Conción 265,1, Festividad de todos los santos, vol. VIII/2-3, pag. 635,637.

${ }^{67}$ Conción 320,9, S. Ildefonso, OC, VIII/1, 491.

${ }^{68}$ Conción 114, Miércoles III semana de Cuaresma, OC, III, 239.
} 
Sólo desde la fe es inteligible la vida religiosa por las renuncias que comporta a placeres y riquezas, por los riesgos y trabajos de comporta. La fe es imprescindible para todo cristiano y, muy particularmente, para los consagrados:

"¿Quién iba a despreciar los placeres y riquezas de este mundo si no tuviera la firme convicción de que había otros mejores y más duraderos? ¿Quién se entregaría gustoso a los trabajos de aquí si no esperase el descanso que ha de llegar algún día? ¿Quién expondría a peligros esta vida si no creyera firmemente que tendrá otra mejor? Si prescindes de la fe, ¿quién iba a trabajar? ¿Quién sería morigerado sin la fe?, ¿quién se privaría?, ¿quién amaría la castidad y la pobreza? ¿Qué otra cosa sino la fe hizo que los mártires soportaran con valor los tormentos y suplicios? ¿Qué sino la fe llevó a los anacoretas a pisotear el mundo con sus pompas y delicias y a llevar una vida solitaria entre fieras y escorpiones? ¿Qué, más que la fe, animó a las vírgenes a luchar en su carne frágil contra su propia naturaleza, en una dura pelea sin tregua? ¿Qué otro motivo sino la fe anima hoy a un incontable ejército de religiosos a vivir en obediencia y pobreza, después de haber dejado a sus padres y allegados? [...] ¡Oh estupendo poder de la fe, [...] Ella es el único cimiento de todo el edificio espiritual; ella es el arranque de la salvación, ella la puerta de la vida, [...] Ella es la estrella esplendorosa que dirige nuestra travesía por el espacioso mar, ella la antorcha que luce en lugar oscuro (2Pe 1,19), y el lucero brillante que alumbra la noche tenebrosa de esta vida. Adondequiera que te vuelvas, pienses lo que pienses, hagas lo que hagas, en todas partes y siempre, te es necesaria la fe. De las otras virtudes, echamos mano según el lugar y tiempo; no siempre rezamos, no siempre ayunamos, no siempre estamos alerta; hay tiempo de compadecerse, tiempo de llorar, tiempo de sufrir, tiempo de dar: Todo tiene su tiempo (Qo 3,1); sin embargo el tiempo de la fe siempre está listo." ${ }^{, 69}$.

Pero Sto. Tomás es consciente de la dificultad de la fe y lo expresa con gran fuerza en una conción en la fiesta de la Sma. Trinidad:

"De entre todos los preceptos de la religión cristiana, no hay ninguna más ardua y difícil que la fe. No intentéis comparar los ayunos, la castidad, la humildad, la paciencia, el abandono del mundo, la penitencia, todas las asperezas y cruces. Todas esas cosas juntas son más ligeras y fáciles que la fe. [...] Pues, por ejemplo, que Dios sea trino y uno, que Dios se hizo hombre, que fue crucificado y murió, que lo dio a luz una virgen, que el cuerpo de Cristo está presente en el sacramento y en cualquier partecita de la hostia, que nuestro cuerpo convertido en polvo ha de resucitar, que brillará más que el sol, que el cuerpo de carne y hueso morará eternamente en el cielo, y que allí habrá vida sin fin en los cuerpos y en las almas después de haber resucita-

${ }^{69}$ Conción 319,7-8, S. Ildefonso, OC, VIII/1, 453,455. 
do...; imponer al hombre, bajo un estricto mandamiento, esas verdades de la fe católica, que están por encima de su entendimiento y de su razón, obligarle a que las acepte en su mente y las mantenga y que en ellas crea firmemente y sin titubeo ni recelo de ninguna clase, y que persevere tan firme en esa confesión que esté dispuesto a morir por ellas, y a soportar cualquier género de muerte antes que titubear o dudar lo más mínimo, y esto bajo pena de condenación al fuego eterno [...] Éste, repito, es el mayor y más difícil de todos los preceptos de Dios." ${ }^{, 70}$

Para justificar la necesidad de la fe recurre a la experiencia humana y a la necesidad que tenemos de creer humanamente lo que no vemos. Lo que Dios nos dice está avalado por su propia autoridad. ${ }^{71}$

A pesar de la valoración de la fe, Sto. Tomás tiene clara la primacía de la caridad. En un bellísimo sermón, pronunciado en Quincuagésima, explicará los diversos caminos para llegar a Jerusalén, es decir, para alcanzar la salvación, resaltando el camino del amor, siguiendo a S. Pablo:

"Habla [el apóstol] Tomás: No sabemos adónde vas, ¿cómo podemos saber el camino? Réplica del Señor: Sabéis adónde voy yo, sabéis asimismo el camino (Jn 14,4). Hay varios caminos a Jerusalén, no solamente uno; pero uno de ellos es fácil, otro trabajoso; uno corto, y otro largo.

«Trabajoso atajo es el del martirio», pero cortísimo. Camino más largo es la penitencia: es áspero, pedregoso y difícil. ¡Cómo lo temen todos! Muchos lo empiezan, pero enseguida se vuelven; [...] El mejor camino es el de la inocencia, pero pocos, poquísimos saben de él. Bueno también el de la continencia, bueno el de la pobreza voluntaria de los religiosos, bueno el del cuidado de los enfermos, la hospitalidad para con los pobres, el reparto de limosnas. En fin, unos caminaban de una manera, otros de otra (1Cor 7,7). Mas el Apóstol, en su carta a los Corintios, nos dice: Yo os enseño un camino más excelente (1Cor 12,31): un camino real, un camino llano, tranquilo, fácil, seguro, ancho, una vía «bien poblada»: Aunque hablara lenguas de los hombres y de los ángeles, etc. (1Cor 13,1). He ahí el camino hacia la celestial Jerusalén. El Evangelio nos dice que subamos, y la epístola de Pablo nos señala el camino. ¡Oh camino real! ¡Oh deliciosa vía del amor! ¿Hay algo más fácil, más grato que amar? [...] Es facilísimo, pues, el camino del amor, ya sea a Dios, ya al prójimo. Así pues, ¡qué fácil es esta ruta! ¡Qué hermoso y agradable el camino! [...] Todos los que han ido a Jerusalén, lo han hecho por este camino. [...]

He ahí el camino: padecer por los demás, morir por los demás, dar la cara por los demás. Ése es el camino. Éste es el camino, hermanos: caminad por él. [...] Pronúnciate en contra de los eclesiásticos que andan en busca de ren-

\footnotetext{
${ }^{70}$ Conción 189, Sma. Trinidad, OC, IV, 567-568.

${ }^{71}$ Cfr. Conción 319, S. Ildefonso, OC, VIII/1, 443, 445.
} 
tas; contra los prelados; contra los frailes que tienen rebuscadas fórmulas de limosnas; contra los hipócritas que, con el pretexto de la oración, devoran las casas de las viudas (Mc 12,40)."72

El don más alto es el amor, porque se nos da Dios mismo. Por eso la virtud principal es la caridad:

"La caridad es no solamente la más excelsa de todas las virtudes, sino también el mayor de los dones de Dios. Mira qué opulenta, qué rica y qué exquisitamente dotada de toda suerte de bienes está la casa de Dios, rebosante en tantos y tantos tesoros y carismas. Yo te aseguro que, si llegas a conocer a fondo todos los tesoros celestiales y todos los inmensos archivos de las riquezas de Dios, no encontrarás nada más valioso, nada más espléndido, nada más apetecible que el amor de Dios. Sin discusión, el mayor de todos los bienes y beneficios que Dios puede otorgarnos es el amor a él. Que pidan otros el don de profecía, otros la ciencia, otros la fe o la castidad, otros la humildad, otros lo que buenamente les plazca: tú, pídele la caridad, el amor a él, porque el más excelente de todos es la caridad (1Cor 13,13). Y la razón de esto es porque, por muchas cosas que te dé Dios, si no te da su amor, se te ha negado a sí mismo, pues el hombre en este mundo sólo por el amor posee a Dios, y justamente poseerlo es amarlo. Así pues, el amor hace tuyo a Dios, lo hace posesión tuya y herencia tuya: y por mucho que tengas, si no tienes amor, tampoco tienes a Dios, ni gozas de él, porque en esta vida goce y amor son la misma cosa. ¿Y de qué te sirve tenerlo todo y no tener a Dios?"73

El lugar prioritario de encuentro con el Señor es el corazón. Una puerta abierta no sólo a los monjes, sino también a los seglares. En este punto se muestra discípulo de Agustín. ${ }^{74}$ Pero para lograr ese objetivo hay que abandonar los apegos carnales, olvidar las costumbres aseglaradas y abstenerse de los vicios del pasado. ${ }^{75}$

En la virtud se progresa desde el corazón:

"Porque cualquier grado en la perfección y cualquier adelantamiento en la virtud hay que intentarlo en el corazón más que en la obra en sí o en las palabras. Dios, en efecto, no se fija en qué o cuánto haces, sino en cuánto adelantas en el deseo y en el amor de él, porque, aunque es cierto que cada uno será juzgado por sus obras, sin embargo el peso de la obra es la caridad del corazón." 76

${ }^{72}$ Conción 55, Dom. Quincuagésima, OC, II, 243-247.

${ }^{73}$ Conción 332,3, Santa María Magdalena, OC, VIII/2-3, 107.

${ }^{74} \mathrm{Cfr}$. Argimiro TURRADO, Santo Tomás De Villanueva, maestro..., 63.

${ }^{75}$ Cfr. Conción 218,2, Dom. XIX de Pentecostés, OC, V, 359,361.

${ }^{76}$ Conción 251,7, Ascensión del Señor, OC, VI, 487. 
Lo mejor que Dios puede darnos es su amor:

"Dios no puede dar nada más excelente que su amor. Esto es lo máximo que puede dar: amar. Del amor viene la predestinación; del amor, la justificación; del amor, la glorificación. El amor es la fuente de todos los bienes; sin él todo es nada, con él, todo lo demás es algo. [...] ¿Por qué nos fatigamos, si no es para agradarte, Señor? "Por pareceros bien, por agradaros", por esto se dejaron despedazar los mártires: para complacerte. Por eso vivieron como salvajes los anacoretas entre peñascos: para agradarte. Por esto mantuvieron las vírgenes un tan duro y continuo combate con su cuerpo: para agradarte con su castidad y su pureza. Éste era el objetivo, éste el motor de todos nuestros deseos, de todas nuestras fatigas, de todas nuestras obras. Porque todos los santos no sirven a Dios o aguantan por la recompensa y el premio, antes bien por agradar a Dios, para mostrarse agradecidos con él.

Señor, si me amas, esto me basta, no busco otra cosa. Ni los santos temen cosa alguna, ni incluso al mismo infierno, tanto como desagradar a Dios. En fin, ni a los propios condenados los hace tan infelices el fuego y el infierno, como el saberse odiados por Dios." ${ }^{.77}$

El amor de Dios logra que los sacrificios, ayunos, obediencias, disciplinas y otros actos de penitencia produzcan gozo en el espíritu.

"Escucha lo que te digo: Ama a Dios y todo lo que a tu cuerpo le resulta trabajoso; será una gozada para tu espíritu. Porque toda práctica corporal, como ayunos, obediencias, disciplinas y otros actos de penitencia, si falta el fuego del amor, son una carga para el alma, pero cuando hay amor de Dios, esos ejercicios duros del cuerpo se convierten en delicias para el espíritu. [...] cuando se ama, o no se sufre o se ama el mismo sufrimiento, y donde hay amor no hay penas. Concluye de aquí lo vergonzoso y deplorable que es no servir a Dios." ${ }^{, 78}$

El amor de Dios lleva a servirle no por el premio sino por sí mismo.

"Sin embargo, los cristianos que trabajamos en la viña del Señor, no miramos tanto a las promesas que se nos hacen como a la gloria de Dios. Sabéis que hay muchos que, por servir a Dios, no sólo se despreocupan de recompensas temporales, sino incluso de las espirituales, y hasta de su propia gloria; muchos que le dicen a Dios con sinceridad: «No quiero servirte por el premio, sino por ti mismo; mi amor no busca sus propios intereses; mi amor es un sentimiento, no un contrato. Amo para amar; amo sólo por amar». Ved ahora si las obras inspiradas en ese amor merecen o no mayor premio que

\footnotetext{
${ }^{77}$ Conción 328,1, San Juan, apóstol y evangelista, OC, VIII/2-3, 37,39.

${ }^{78}$ Conción 44, Dom. Septuagésima, OC, II, 63.
} 
otras, realizadas incluso con más trabajo, pero también por algún interés, sea temporal, sea espiritual.",79

\section{LA VIDA RELIGIOSA COMO ESTADO DE PERFECCIÓN}

Una afirmación sobre la vida religiosa que la ha descrito como una de sus características esenciales hasta el concilio Vaticano II y que comparte Sto. Tomás es la vida religiosa como estado de perfección. No quiere decir que cada religioso sea perfecto, pero sí que ha abrazado un estado de perfección. Una afirmación que se sustenta sobre un texto del Evangelio:

"al religioso, que toma el camino de la perfección, Jesús dijo: Si quieres ser perfecto, anda y vende cuanto tienes, y dáselo a los pobres; ven después y sigueme (Mt 19,17-21). Si, como veis, habéis querido subir a la vida de la perfección, no contentándoos con la vida común, y tomar el camino de su pueblo escogido, Israel, es menester que hagáis más que el seglar; que no solamente habéis de guardar los mandamientos, pero habéis de hacer lo que os añade aquí Dios [...] ${ }^{800} \mathrm{Al}$ seglar manda Dios Amarás al Señor tu Dios y a tu prójimo como a ti mismo (Mt 22,37-39).

Para distinguir entre la vocación del seglar y la del religioso utiliza el icono de Marta y María.

“...los caminos del Señor el Salmista los reduce a dos, con estas palabras: Todos los caminos del Señor son misericordia y verdad (Sal 24,10). Por estas dos veredas, misericordia y verdad, camina toda persona santa hacia la tierra de promisión. Porque, en efecto, o se dedica como Marta a servir celosamente en obras de misericordia, o contenta exclusivamente con la contemplación de la verdad, descansa con María a los pies de Jesús (Lc 10,38-41). El primero es el camino de los seglares; el segundo, el de los monjes. [...] cada uno persevere en la vocación a la que ha sido llamado (1Cor 7,20; Ef 4,1), pues aquel que cambia muchas veces de camino, andando de trocha en trocha, al corretearlos todos, no avanza por ninguno." ${ }^{, 81}$

El religioso ha elegido, como María, la mejor parte.

"Practicad, os insisto, en la tierra lo que vais a hacer siempre en el cielo, y allí no hay otra ocupación que la alabanza. [...] Sentaos, pues, hermanos, a los pies de Jesús, junto con María, para escuchar en silencio su palabra y sa-

\footnotetext{
${ }^{79}$ Conción 46, Dom. Septuagésima, OC, II, 99.

${ }^{80}$ Plática y aviso al religioso que toma el hábito, OC, X, 217. Esta obrita la publicó también Santos SANTAMARTA, en Obras de Santo Tomás de Villanueva, Madrid, BAC, 1952, 562-575.

${ }^{81}$ Conción 329,7, S. Lesmes, OC, VIII/2-3, 77.
} 
ciaros de la leche de sus consuelos (Is 66,11). Acudid asiduamente a esta escuela, escuchad al Maestro de la vida, sabiendo que sólo para eso estáis ahí y que únicamente para eso habéis entrado en el claustro religioso; ninguna otra cosa os importa, no se os impone otro menester.[...] Ésta es la tarea del monje, éste su oficio. Ésta es la suerte de los que recibieron con gozo el yugo del Señor. Feliz la vida que se gasta en ese ministerio, la que tiene asignado sosiego en lugar de trabajo, ocio en vez de actividad, silencio a cambio de trapicheo. [...] Al monje no se le impone esfuerzo físico alguno, sino el de no esforzarse, es más, el de descansar con su Dios y pasar el día entero deleitándose en él. ¡Oh suerte sin igual!, ¡oh vida dulcísima!, ¡oh paraíso de delicias, al que se promete otro paraíso todavía más agradable! Esfuerzo sin esfuerzo, trabajo sin trabajo, ocio más grande que cualquier negocio". ${ }^{82}$

En el monasterio se vive alejado de cuidados materiales y centrado sólo en Dios. Es una responsabilidad el cumplir con el género de vida elegido:

"nosotros, que hemos hecho profesión de vida espiritual, jcon qué esmero, con qué atención debemos preocuparnos de ser lo que hemos prometido, hasta alcanzar la belleza de costumbres propuesta!

Porque tampoco en el monasterio hacemos otra cosa: estamos alejados de toda clase de preocupaciones y negocios, no nos apremia ni el cuidado de los hijos, ni la servidumbre de la casa, ni los asuntos de la familia. No sembramos, ni cosechamos; no estamos en la milicia, ni en la fábrica; vivimos libres de todo cargo y actividad exterior, para que nos ocupemos sólo de nosotros. Con el trabajo y actividad de los de fuera, tenemos vivienda, alimento, vestido y demás cosas necesarias para la vida. Nadie nos perturba, nadie nos molesta, nadie nos inquieta, y por todo esto no se nos exige otra cosa sino que seamos mejores.

¿Qué buenísima suerte y condición privilegiada la nuestra! Por dedicarnos a cultivar la heredad de nuestro corazón, recibimos una recompensa, se nos da un salario. ¿Qué vamos a decir en el juicio? ¿Qué excusa tendremos si encuentran que somos carnales e incultos? La preocupación podrá de algún modo ser una excusa para las vírgenes seglares, pero a nosotros, ¿qué otro remedio nos queda más que callar la boca ante el juez, como aquel siervo inicuo del Evangelio? (Mt 22,13).".83

En sus descripciones de la vida religiosa encontramos dos líneas de exposición. Por una parte, una aproximación positiva a lo que la vida religiosa significa en la Iglesia, lo que aporta a cada individuo que forma parte de la misma, el camino de perfección que debe seguir quien la practica. Por otra, en cambio, los

\footnotetext{
${ }^{82}$ Conción 284,5-6, Asunción de María, OC, VII, 461-465.

${ }^{83}$ Conción 312, Sta. Dorotea, OC, VIII/1, 321.
} 
riesgos y errores que acechan la vida de muchos religiosos, que hacen alejarse a muchos del ideal profesado.

En el tratado titulado Plática y aviso al religioso que toma el hábito, escrito sólo en español, hace una síntesis del camino religioso que espera a quien sigue al Señor abrazando la vida religiosa.

El primer aviso para el novicio es que ha dejado Egipto, es decir, el mundo. La tierra prometida es la religión, que no es como el mundo del que sale, con las recreaciones, prosperidades, descansos, deleites, sosiegos y holguras corporales de la vida del mundo. La tierra que le espera es áspera, llena de cuestas, sin las delectaciones y consuelos de Egipto. Como terreno montuoso no se puede regar con las aguas de abajo sino que se ha de subir con las virtudes aguardando las lluvias del cielo. Esa lluvia es la gracia de Dios que hará suave al yugo por la carga del amor. ${ }^{84}$

Invita al novicio a no buscar las aguas hediondas de abajo. Cuanto menos las busque más abundante será la lluvia de la gracia. Sentirá la tentación de volver a esas aguas de abajo, por instigación del demonio. Cuando viera crecer la tentación debe "desecharla y raparla luego de vos". El rapado de la cabeza, como el del cuerpo de los escribas en el Antiguo Testamento, significa que debe olvidar los pensamientos y deseos terrenos. El religioso no debe acordarse de las ollas de Egipto, sino resistir la tentación. ${ }^{85}$

Aparentemente, Sto. Tomás centra la vocación religiosa en el claustro y la contemplación. Hace pocas referencias a servicios eclesiales concretos, dentro o fuera del convento, como serían la predicación o la atención a los más débiles, que forman parte de la vida activa. Los conventos de mendicantes tenían una importante actividad pastoral en las propias iglesias y frecuentaban las universidades, aunque Sto. Tomás no lo menciona. La actividad hacia afuera la ve sólo posible como fruto del desbordamiento de la riqueza interior.

Pero aunque la meta sea la contemplación, no se excluye la vida activa, tanto ascética como apostólicamente, sobre todo para quien no se vea capaz de subir el monte de la contemplación. Así lo explica al novicio que va a tomar hábito:

"Y por eso si vieres que no tenéis ánima o espíritu para subir al monte de la contemplación, ejercitaos en el valle, en lo bajo, y allá os podéis quedar y andar en la vida activa, que es también buena, aunque vale poco sin la otra; y por eso ejercitaros habéis lo mejor que pudiereis en la contemplación, aunque sea poco, porque sin ésta no haríais nada ni os podríais ejercitar en la activa; que la contemplación os ha de favorecer y dar alas para que bien os ejercitéis en la activa y,

\footnotetext{
${ }^{84}$ Cfr. Plática y aviso al religioso..., OC, X, 211.

${ }^{85}$ Cfr. Ibid., 212-213
} 
porque os da este aviso nuestro Señor, penséis de esta activa también, porque no os descuidéis, que si no pudiereis alcanzar la contemplativa, no quedéis también sin la activa, que así acontece a muchos que buscando la contemplativa, ni hallan ésta, ni alcanzan, ni hacen la activa, y quedan sin ninguna de ellas." ${ }^{, 86}$

Considera erróneo empeñarse en realizar obras buenas que pueden ser subterfugios para derramar la propia dispersión.

"Se ve a muchísimos, abrasados por un celo indiscreto de caridad, poniendo todo su esfuerzo en curar las dolencias de las almas cuando ellos mismos están más enfermos que nadie. Se ve a monjes que, dejando el claustro, vagando de acá para allá por la ciudad, se implican espontáneamente en asuntos de otros: unos, entregándose indiscretamente, no sin grandísimo detrimento para su propia lámpara, a proveer de sustento a los pobres, otros a visitar a las viudas, otros a instruir a la gente del pueblo, otros a recomponer amistades rotas, disimulando bajo el velo de la caridad su propia dispersión. Esto no es caridad, sino una gran necedad; es traspasar los límites de la propia vocación, apagar la lámpara propia para encender las de los otros.

Es tarea de perfectos y de personas de virtud probada, prestar atención a los demás. El que ya se basta a sí mismo, ése que supla las carencias de los otros; el que tiene de sobra para sí, reparta aceite, si no teme que le falte a él. Pero si teme que le pueda faltar y recibe encargo de su superior de que reparta con los otros, obedezca con toda confianza. Porque hay algunos que, gastándolo, tienen en mayor abundancia ${ }^{987}$,

Parece bien a Sto. Tomás la actividad, pero realizada por religiosos probados en la virtud y la obediencia, que no descuidan su propia vida espiritual, no sea que pierda el alma por servir a los demás.

La ociosidad es enemiga de la vida espiritual por eso la critica en los religiosos. En un sermón dirigido a las religiosas invita Tomás al "laboreo de la dedicación espiritual y el calor de la caridad" ${ }^{88}$. Y en otro: "quien no hace el bien que debería hacer perecerá" 89

No obstante, las tentaciones juegan un importante papel en la vida del monje y del cristiano. Ayudan a permanecer despiertos y a pedir la gracia para superarlas. "si desapareciera la tentación, tal vez me quedaría dormido". 90

Aconseja al novicio que mire bien a lo que se compromete, no sea que se quede sin ninguna de estas dos vidas: la terrenal y la eterna.

${ }^{86}$ Plática y aviso al religioso..., OC, X, 213.

${ }^{87}$ Conción 311,8, Sta. Dorotea, OC, VIII/1, 301,303.

${ }^{88}$ Conción 41,1, Dom. Septuagésima, OC, II, 4.

${ }^{89}$ Conción 311,4, Sta. Dorotea, OC, VIII/1, 295.

${ }^{90}$ Conción 76,5, Dom. I Cuaresma, OC, II, 477. 
Ante el temor del rigor de la vida religiosa, Tomás invita a no tener miedo. En la vida religiosa la ascesis es llevadera y no resulta difícil para el alma devota:

"en la vida religiosa vemos que se hacen cosas muy pesadas para algunos y que para otros son muy llevaderas y fáciles. Aunque, ciertamente, para un alma devota no hay nada difícil en la religión."

El Señor no deja de buscar, un día y otro, obreros para su viña. Su invitación se dirige a nosotros. Unos vienen a la viña a primera hora de la mañana, otros a la de tercia, en la adolescencia. Otros a la de sexta, en la juventud, o la de nona, en la senectud. Incluso a la hora undécima, al final de la vida. Pero él no rechaza a nadie: Al que viene a mí, yo no lo desecharé (Jn 6,37).

Valora la incorporación a la religión en diferentes estadios de la vida, incluso los que llegan a la hora undécima, que no reciben reprensión del Señor, sino que el Señor valora su trabajo, aunque haya sido breve. Dará la misma paga a los primeros y a los últimos, si también estos han trabajado en la viña. Pero hace elogio de la llamada a primera hora y de quienes consumen toda su vida en el servicio de Dios.

"¡Oh que gran bendición la de los niños y niñas que abandonan el siglo en la edad de darse a los juegos, vanidades y diversiones mundanas, y se entregan, ya en esos años, a las oraciones, las vigilias, los ayunos y plegarias! Estos son preservados por Dios con alabanzas de ternura, para que no vean ni experimenten la corrupción ni la vanidad, sino que, cual ángeles celestiales, puros y sencillos, separados del mundo, morando toda su vida en el claustro, pasen de la celda al cielo. Grande, muy grande es la misericordia de Dios para con ellos. [...] Empero, a los que vienen tarde, no les es tan fácil elevarse sobre sí mismos: tienen bastante con llorar sus pecados del siglo, despojarse del hombre viejo y dejar las malas costumbres, frenar los hábitos perniciosos y oponerse a los vicios [...] Eso sí, cuanto más tarde hayan llegado, tanto más fervorosos y diligentes deben ser" ${ }^{\prime 2}$.

Los votos son atajos o senderos para llegar al cielo.

"Vino Dios al mundo y nos mostró tres caminos, «tres atajos», contrarios a los anteriores por los que, en poco tiempo, pudieran llegar los hombres al cielo.

Frente al primero de antes, abrió el sendero de la obediencia. Contra el segundo, la senda de la castidad; y opuesto al tercero, el camino de la pobreza. Les puso guías, que fueran delante, y él en persona los precedió.

[...] Allí estaba Benjamín, el más pequeño, Francisco, un magnífico guía.

\footnotetext{
${ }^{91}$ Conción 312, Santa Dorotea, virgen y mártir, OC, VIII/1, 317.

${ }^{92}$ Conción 41,2, Dom. Septuagésima, OC, II, 9.
} 
¿Quién hubo en el mundo tan pobre como él? Él se desposó con la pobreza, la amó tiernamente, por ella sintió grandísimos celos. Si sabía de alguien más pobre que él, al momento se lamentaba, como si le hubieran quitado la esposa. Pobre en el comer, pobre en el vestir y en el lecho, malmirado y objeto de desprecio para todos; su gloria era sufrir desprecios, por lo que no quiso que sus frailes tuviesen nada en la comunidad: les dejó en herencia su propia pobreza" ${ }^{933}$.

Utiliza Sto. Tomás diversas imágenes para identificar a los religiosos: como aves, por estar llamados a volar por las alturas, menospreciando las cosas de la tierra $^{94}$, o como higuera,

"cuya fruta es muy dulce [...] lo mismo que el higo reúne pacíficamente a muchos granos bajo una misma piel, así también los religiosos se agrupan varios bajo una misma regla de vida [...] Además, las hojas de la higuera se parecen a una mano humana; también las palabras de los que viven en el claustro deben ir acompañadas de buenas obras y adaptarse a ellas". ${ }^{95}$

La vida religiosa no es camino para todos.

"por eso os digo que este camino, que es alto, no es para todos: que valiera a algunos más que quedasen en el siglo que no querer traer su mujer acá, que es su carne",96.

La vocación religiosa no es para todos, ni es una obligación, sino una invitación:

"Ahora bien, no quiero que nadie, al escuchar estas palabras del Señor nuestro Salvador, se considere obligado a renunciarse a sí mismo y a todo lo que posee como tienen por costumbre hacer los religiosos en su profesión. Éste es un consejo que se sugiere, no un precepto que se impone. Negarte a ti mismo y a tus cosas hasta esos extremos, no es algo imprescindible para la salvación, $[\ldots]$ ¿Qué es entonces negarse a sí mismo?" ${ }^{97}$ En el caso de los religiosos lo identifica con los votos

Gracia y ascesis son un binomio esencial en la vida religiosa. Gracia porque sin la ayuda de Dios es imposible avanzar. Ascesis porque sin colaboración y esfuerzo del religioso, el camino estaría bloqueado y sería imposible avanzar. Este subrayado de la necesidad del esfuerzo humano resulta importante por el

\footnotetext{
${ }^{93}$ Conción 318,6-7, S. Francisco de Asís, OC, VIII/1, 433,435.

${ }^{94}$ Cfr. Conción 195,1-2, Dom. IV Pentecostés, OC, V, 45; Conción 298,7-8, Santa Ana, OC, VIII/1, 101; Conción 337,5, San Matías, OC, VIII/2-3, 239.

${ }^{95}$ Conción 200,6, Dom. VII Pentecostés, OC, V, 107.

${ }^{96}$ Plática y aviso al religioso..., OC, X, 214.

${ }^{97}$ Conción 369,7-8, Fiesta de un mártir, OC, VIII/2-3, 717,719.
} 
contraste con la concepción protestante, aunque en ningún momento dejará entrever que la perfección sea una conquista humana, como denunciaba Lutero a la vida religiosa de su tiempo. Nada, ni siquiera el esfuerzo ascético que implican los votos es posible sin la gracia. Pero es necesaria la colaboración humana. Aunque la vida espiritual dependa del todo de la gracia y de la acción de Dios, es erróneo ampararse en esa conciencia para no colaborar con la gracia:

"Es tentación dejarlo todo en las manos de Dios, ponerse totalmente a disposición y a las órdenes de Dios y no hacer lo que está dentro de las posibilidades de cada cual." ${ }^{.98}$

La confianza hay que ponerla no es en las propias fuerzas, sino en la gracia de Dios, sin la que es imposible caminar hacia la perfección. La gracia es la que hace fiel a la opción hecha. Es el Señor quien da la lluvia del cielo que permite progresar en la virtud.

Por ese motivo, Sto. Tomás exhorta al novicio a rogar que el Señor le otorgue esa lluvia primera, que lave los pecados de la vida pasada y le abra a otra lluvia de más dulzor, que se da a quienes han renovado y desechado lo viejo. ${ }^{99}$

Explica también el papel insustituible de la gracia y la necesidad de la colaboración humana en una conción de :

“... la castidad es un don de Dios, no una conquista humana. Pero, a pesar de eso, nosotros, por nuestra parte, no cesamos nunca de golpear ese mar con la vara de la disciplina y de la penitencia, como hizo Moisés (Ex 14,21). Con el soplo de Dios y el golpeo de la vara termina por secarse el mar Rojo de nuestra concupiscencia carnal."100

La lucha por el control de la concupiscencia está muy presente en su predicación. Es menester que el espíritu esté sobre la carne y para ello es necesario macerarla para sujetarla y tenerla siempre debajo y vivir enteramente según el espíritu. Para el religioso su única referencia debe ser Dios mismo. No debe dejar nada para de sí mismo para el mundo, porque "entero le quiere Dios, no le quiere dividido $[\ldots]$ el día que dividiereis vuestro corazón, daos por muerto para con Dios"101

Desenmascara las argucias del demonio que primero le presenta la vida religiosa como inalcanzable y luego le impele a ejercitarse en una ascesis absurda que le autodestruirá física y espiritualmente.

\footnotetext{
${ }^{98}$ Conción 81, Dom. I Cuaresma, OC, II, 549.

${ }^{99} \mathrm{Cfr}$. Plática y aviso al religioso..., OC, X, 221

${ }^{100}$ Conción 56, Dom. Quincuagésima y Miércoles II Sem. Cuaresma, OC, II, 253.255.

${ }^{101}$ Plática y aviso al religioso..., OC, X,219.
} 
"La vida religiosa es una vida sosegada, pacífica, segura, deleitosa, alegre, razonable, atractiva y muy grata. La vida del siglo es agitada, trabajosa, inquieta, arriesgada, amarga, toda llena de ansiedades y preocupaciones. [...] Una vez que el soldado cristiano se ha percatado de la falsedad de los referidos temores y está ya caminando animosamente por el camino emprendido de la perfección [...] el diablo le ataca por otro flanco: ya que no ha podido impedirle abrazar la vida religiosa, intenta reírse de él y engañarle. Le mete en la cabeza infinidad de frivolidades y multiplica sus ensoñaciones de ilusoria fama; exagera y magnifica hasta más arriba de las nubes cualquier insignificante acto de piedad y devoción [produciendo engreimiento] [...] la herida que hace no es superficial. Ésta se clava sobre todo en los novicios y principiantes, los cuales, desconocedores de los tesoros del espíritu, dan el máximo aprecio a todo lo que les llega teñido de fervor o devoción, y con ello ya se piensan que han tocado las cimas de la perfección. [...] ¿Qué hará el demonio cuando ni con esa arremetida tan cruel ha sido capaz de apartar de la santidad y justicia al cristiano amparado por la verdad? Vuelve a sus técnicas y embustes, a ver si, a quien no pudo derrotar por la fuerza, puede abatirlo con el engaño: Se transfigura en ángel de luz $(2$ Cor 11,14$)$ para engañar, bajo apariencias de piedad, al amante de la santidad y de la honradez. Así, al que practica el ayuno, le persuade a que ayune más y mucho más; al que ora, al que se ejercita en la vigilia, y al trabajador, lo mismo. De ese modo, a los tres días, esa persona se ha convertido en un ser inútil por el ayuno y la vigilia exagerados. Aconseja excederse, para que se quede uno inservible, y al que está corriendo, le aguijonea más para que caiga. ¿Quién podrá explicar todas sus artimañas y engaños? Al religioso bueno y al monje honesto, so pretexto caritativo de fomentar la paz entre los hermanos, de ofrecer un solaz a los débiles y otros mil ejercicios de compasión, lo lleva fuera del convento para que así, vagando por las plazas, se infecte de sensualidad, se embriague de curiosidad, se hinche de ambición, se desquicie por los afanes seculares y así, alejándose del fervor de la devoción, se entibie y se vuelva frío del todo." ${ }^{, 102}$

En una conción del domingo primero de cuaresma describe el carácter progresivo de la tentación, donde el exceso en la ascesis o los actos de piedad pueden ser el último peldaño:

"El desarrollo de las tentaciones es el siguiente: Primero, nos pone delante la dificultad de la penitencia y de las buenas obras [...] Luego, si eso no ha lugar, destruye las buenas obras por medio de la vanagloria [...] Si rechaza el viento de la vanagloria, se le proponen placeres y riquezas como bienes sólidos, que debe buscar valiéndose de la hipocresía [...] Y, si lo desprecia todo, se transfigura en ángel de luz, tentando bajo apariencia de consejero bueno: he ahí el demonio del mediodía. Por ejemplo: Si no puede convencerte de que dejes el ayuno, te per-

${ }^{102}$ Conción 78, 7-8, Dom. I Cuaresma, OC, II, 513-519. 
suade a que te pases en él. Otro ejemplo: Si no puede hacerte desistir de que te hagas religioso, después que has entrado, intenta que te vayas al yermo, para que te disipes y te perviertas al no tener consuelo."

Es interesante comprobar que Sto. Tomás pide prudencia y equilibrio en las prácticas de piedad, incluso en las predicaciones de cuaresma.

“Aviso a los religiosos: manténganse alerta, porque a diario está el demonio sugiriéndoles que hagan panes de las piedras de la austeridad y del rigor." 104

Ideas parecidas expresa predicando en la Epifanía, lo que evidencia su convicción sobre este punto, referido a las prácticas penitenciales y a la misma oración:

"debe estar muy alerta aquel que lo hace todo con gran deleite, no vaya a ser que, al seguir este gusto, destroce su cuerpo con una inmoderada penitencia, y luego tenga necesidad, no sin gran detrimento de las prácticas espirituales, de dedicar sus cuidados a su cuerpo debilitado. Por eso es preciso dejarse iluminar por la luz de la discreción, que es la madre de las virtudes y el colmo de la perfección. Esto está resumido en aquella norma: «Nada en exceso». [...] Del tesoro de tu corazón ofrece una oración sencilla, como incienso al Señor. [...] ¿Acaso hay que estar orando sin cesar y el día entero? No es imposible orar continuamente, según creen algunos: porque siempre ora el que siempre ama, y el que crece en deseos lo está bendiciendo siempre."

Las penitencias son amargas, como la mirra, pero debe ser administrada con prudencia:

"La mirra es amarga, pero muy útil y provechosa para el cuerpo, ya que preserva los cuerpos de la corrupción, de los gusanos y de la lividez: así es toda clase de renuncia y la práctica de la penitencia. Con ella se evita que las carnes se pudran con las liviandades, según está escrito: Se pudrieron las bestias en sus excrementos $(\mathrm{Jl} 1,17)$. Únicamente procura no pasarte: que atenúe la fuerza de la carne, no que apague tus fuerzas; que no se la derrame sino que se la destile, conforme está escrito: Mis dedos destilaron mirra (Cant 5,5)."106

Así pues, las prácticas penitenciales exageradas no son virtuosas. La penitencia debe ser ejercitada con moderación, para que no haya que cuidar un cuer-

\footnotetext{
${ }^{103}$ Conción 76,4, Dom. I Cuaresma, OC, II, 471, 473.

${ }^{104}$ Conción 79,3, Dom. I Cuaresma, OC, II, 527.

${ }^{105}$ Conción 243,7, Epifanía, OC, VI, 343.

${ }^{106}$ Conción 242,10, Epifanía, OC, VI, 327.
} 
po enfermo. Como dice en la conción 19, predicada en adviento, "la perfección de la vida está en la caridad más que en la austeridad." ${ }^{107}$ En este tema Sto. Tomás, como S. Agustín, no es rigorista. Como recordábamos el biógrafo de Sto. Tomás Miguel Salón considera que pudo influir este aspecto de moderación en su elección de la orden de San Agustín.

Apreciación interesante de Sto. Tomás, sobre todo teniendo en cuenta el contexto histórico con que fue pronunciada, es el afirmar que la fe es un acto libre, que no puede ni debe ser impuesto, como se hace en el mundo musulmán. Lo considera aberrante, mientras que la oferta del Evangelio respeta a la persona. A nadie debe imponerse la fe, ni puede imponerse la vocación religiosa:

"Por tanto, si alguno quiere venirse conmigo...; [Cristo dice:] yo no obligo a nadie, ni rechazo a nadie, esto lo dejo a su libre decisión y voluntad, yo no acepto servicios a la fuerza, no consiento que nadie me sirva contra su voluntad, [...] No quiero que nadie sea bautizado contra su voluntad; no quiero que a nadie le fuercen a ir a misa; el que quiera de buen grado, que se comprometa y se entregue a ello. Esto se dice contra aquellos padres que en nuestros días hacen monjas a sus hijas contra su propia voluntad. [...] ¿Qué tiene de sorprendente que aquel depravadísimo Mahoma arrastrara tras sí a medio mundo en muy poco tiempo, soltando los frenos de los vicios y otorgando licencia para gozar de los placeres, obligando a los que se resistían, no con la palabra, sino con la espada? Tú, en cambio, Señor, no lo hiciste así: tú, ¿qué dices? Si alguno quiere venir en pos de mí... Tú invitas, no arrastras; llamas, no obligas; atraes, no empujas. Tú, en efecto, no quieres privar al hombre de su dignidad de merecer ante ti, porque se habrá sometido gratuita y voluntariamente." 108

Forzar la vocación de los hijos está vinculado frecuentemente a la simonía:

"Habiendo visto cuán abominable pecado sea el de la simonía, bastaría ver que una de las causas por que el estado eclesiástico está tan perdido es por esto.

Mirad bien los padres, que procuráis dignidades eclesiásticas a vuestros hijos, por qué medios las procuráis. Que esto sea verdad, que el padre hace oficio de Dios, al cual toca la elección ya ahora: «Éste será para el mundo, este otro para Iglesia». ¿Qué sabéis si Dios lo tiene escogido para eso? Y así hay tantas religiosas inquietas y tantos malos eclesiásticos. Deja la elección a Dios. [...] Los padronazgos de los beneficios, ¿a quién los dais? Que se comete simonía, aunque no haya dinero, servicios temporales, ruegos, etc. Cuando a un lujurioso das un beneficio, entonces entra un puerco en la Iglesia; cuando a un acuchillador renci-

\footnotetext{
${ }^{107}$ Conción 19,4, Dom. III Adviento, OC, I, 323.

${ }^{108}$ Conción 368,2, Fiesta de un mártir, OC, VIII/2-3, pag. 693.
} 
lloso, entra el perro, et sic de aliis. Y así hay tanta perdición. Si tienes una hija, miras que el marido sea tal, y desposas a la Iglesia con un desenfrenado, y así como entra por medios carnales, o por parentesco o amistad, y no por idoneidad y virtud, así vive después como vive."109

Por otra parte, cuando existe verdadera vocación no hay resistencia posible de los padres para seguirla:

"Pon como ejemplo práctico el de un adolescente que quiere entrar de religioso porque Dios le llama: ni los padres, ni los hermanos, ni los parientes pueden impedírselo por mucho que con ruegos, lágrimas, súplicas o promesas le presionen." 110

Tiene expresiones de elogio para cada uno de los votos que configuran la estructura fundamental de la vida religiosa. ${ }^{111}$ También sobre la clausura:

"La viña necesita dos cosas: una cerca y un cierre. La cerca es la guarda de los sentidos; el cierre es el silencio. Vista, oído, gusto son ventanas por donde entra la muerte. Es preciso cerrar bien. ${ }^{112}$

Alaba a las monjas por haber cerrado esos portones, para conservar la viña. Elogia por ello la clausura e invita a conservarla. "Lo que el ojo no ve, la carne no lo apetece"

La vida de entrega a Dios no es exclusiva del religioso. También se le exige al sacerdote, en mayor grado que al simple fiel. Lo ha estudiado Arturo Llin. Aunque es más valiosa la vida contemplativa que la vida activa, en el sacerdote deben conjugarse ambas en lo que sería una vida mixta. El eclesiástico debe ser un contemplativo llamado a la acción a través del apostolado. Debe practicar las virtudes y amar los consejos evangélicos, pues gracias a ellos mejorará la calidad de su ministerio y la credibilidad ante los fieles. En sus sermones y opúsculos castellanos Sto. Tomás ha plasmado la doctrina teológica y pastoral sobre el sacerdocio, basado en la Biblia, la teología, la filosofía, la moral, la ascesis y la historia. Se percibe la preparación humanística, filosófica y teológica de Alcalá, el estudio de la Biblia y los Santos Padres, y la oración reflexiva son la cantera de sus conocimientos. ${ }^{114}$

\footnotetext{
${ }^{109}$ Conción 432*, Séptimo precepto del decálogo, OC, IX, 311.

${ }^{110}$ Conción 21, Dom. III de adviento, OC, I, 359.

${ }^{111}$ Distingue cuatro clases de pobreza, cfr. Conción 360,6-7, Todos los santos, $O C$, VIII 2/3, 567. Sobre la pobreza como primer paso en el camino de la perfección, cfr. Conción 361,9, Todos los santos, $O C$, VIII/2-3, 587, y también: Conción 359, Todos los santos, $O C$, VIII2/3, 547.

${ }^{112}$ Conción 41,5, Dom. Septuagésima, OC, II, 15.

${ }^{113}$ Ibid.

${ }^{114}$ Cfr. Arturo LLIN CHAFER, “La espiritualidad sacerdotal...”, 94, 88
} 


\section{EL CAMINO DE LA PERFECCIÓN.}

El camino de la perfección que persiguen los consagrados es ligero, como promete el Señor (Mt 11,30). No todo es dureza en el camino.

"Es un yugo, ciertamente, lo que ponéis sobre vosotras -dice a las vírgenes-, pero un yugo suave; es una carga la que tomáis, pero es ligera, no aplasta, sino que sostiene; no abruma, sino que reanima; no pesa, sino que da alas $[\ldots]$ Hay también, entre las escabrosidades de la perfección, praderas verdegueantes acá y allá, fuentes gratísimas, bosquecillos amenos en los que el caminante recobra más energías que cansancio le produce el camino. Y superadas estas lomas, sonríe allá arriba una dilatada llanura, un panorama apacible, una mansión de delicias, que es todo un placer, en la cual, tan pronto como se entra, quedan olvidados por completo todos los trabajos pasados, porque el trabajo es breve y el solaz inenarrable. Permaneced, por tanto, firmes y preparaos para la felicidad futura: sabed que llegará el tiempo en que no os dará tristeza el recuerdo de estos trabajos. [...] La dureza de esta peregrinación más que en el camino está en los pies del caminante, que están embarrados por "el peso de las pasiones carnales, de los deseos y preocupaciones temporales. En efecto, aplastados por ese peso y aprisionados los pies del alma, es decir, los afectos, por semejantes grilletes, caminan con penosa lentitud". Invita, por ello a desatar las ligaduras de los pecados y lanzar lejos los fardos de las pasiones para que resulten asequibles las cumbres de la virtud." 115

Sto. Tomás es muy organizado en sus exposiciones. Ordena los contenidos y los expone sistemáticamente de modo muy didáctico. Afirma que el camino de la perfección tiene sus tramos y por eso se sirve de imágenes tomadas de la naturaleza, con base en el Evangelio, o bien construidas a partir de los propios contenidos que expone.

De la naturaleza toma dos ejemplos: el crecimiento de una planta y el laboreo de la viña.

La planta comienza como semilla; se desarrolla como una hierbecita, formará la espiga y, por fin, el trigo. Esta comparación se encuentra en el Evangelio para explicar el Reino de Dios (Mt 15,13). El que emprende este camino tiene que ser paciente:

"Tú ¿por qué te aceleras, por qué te entran prisas, por qué te angustias si no lo has conseguido, si aún no has llegado, si aún no has alcanzado la meta? Pablo, después de haber penetrado en el cielo y recorrido el paraíso $(2 \mathrm{Cr}$ 12,3ss), no consideraba haber llegado todavía a la perfección (Flp 3,13), y tú,

${ }^{115}$ Conción 279,8, Visitación B Virgen María OC, VII, 327. 
fraile o monja de ayer, ¿ya deseas haberla alcanzado? Espera en el Señor, se valiente, ten ánimo y espera en el Señor (Sal 26,14). El camino de la perfección hay que recorrerlo a pie, no pasarlo volando: se necesita mucha paciencia y ánimo esforzado para llegar al final. Sólo con el esfuerzo diario podrás llegar adonde tienes prisa por llegar. [...] Hay algunos convertidos al Señor que quieren llegar rápidamente a la cumbre de la perfección, saltando como las picazas evitando los espacios intermedios; para éstos, esa forma de salir termina casi siempre en desastre. Pues al entrar en la vida religiosa y tan pronto como pisan el umbral, lo primero que deberían hacer era examinar con cuidado su conciencia, pensar con ánimo contrito en su vida pasada y en los años transcurridos malamente llorar largamente los pecados cometidos, emplearse fielmente en ejercicios de humildad y obediencia, dedicarse con asiduidad a las lecturas santas y a la meditación. Y, sin embargo, dejando de lado todo esto, se entregan con ardor e insolencia a lo que es propio de los perfectos, discuten sobre las sagradas Escrituras, predican asiduamente en público, pretenden ponerse por delante de los mejores y, por parecer más religiosos, buscan ávidamente los gozos del espíritu y las especulaciones celestiales antes que la limpieza del corazón. Sin embargo, estos precipitados, lo mismo que suben de forma antinatural, así también caen con suma rapidez." 116

Al laboreo de la viña, que demuestra conocer bien, se refiere en varios sermones para describir el trabajo espiritual que debe afrontar cada cristiano y muy particularmente las religiosas, a quienes dedica una conción personalizada.

En el cultivo de las viñas distingue cuatro labores: abrirlas para que recojan el agua de lluvia, el rocío y el calor; cavarlas repetidamente para que no echen maleza y espinas; podar los sarmientos secos e inútiles, para evitar que se le vaya la fuerza en madera y no en fruto; renovarla, porque las viñas envejecen y mueren.

Hay que desear la lluvia: sin deseo el alma no está capacitada para recibir la gracia.

"La boca del alma es el deseo por el que se atrae el espíritu. [...] El alma que no desea, que al menos desee desear",117.

Pero, además, hay que cavar, podar y renovar la viña. En cada una de estas tareas se extiende Sto. Tomás, aplicándolo a la vida del espíritu. Sobre la renovación dice:

La renovación se realiza "por medio de ejercicios espirituales, leyendo, meditando, orando, contemplando, prestando atención a los ejemplos

\footnotetext{
${ }^{116}$ Conción 279,9, Visitación B Virgen María, OC, VII, 331.

${ }^{117}$ Conción 41,3, Dom. Septuagésima, $O C$, II, 11
} 
de los santos, entregándose a la alabanza divina. Todo esto es lo que renueva el espíritu y le hace permanecer siempre fecundo, y que permite los rebrotes de nuevos mugrones y 'pimpollos'. - en este trabajo el alma nunca debe parar, pues así como el ejercicio de la penitencia es necesario para ablandar el corazón, así lo es también la práctica de la oración y de la contemplación para renovar el espíritu y reponer fuerzas y virtudes para que no envejezcan y mueran"118.

Menciona la viña para referirse a peligros que acechan la vida espiritual de las religiosas:

"Vemos a veces a una novicia fervorosa, aplicada, devota, alegre, entregada toda ella al servicio de Dios: es que la viña está en flor. ¡Ojo con el cierzo! Mira que no sople desde el siglo el viento de la tentación, el recuerdo de los gustillos, los entretenimientos y vanidades. $\mathrm{Y}$ que no comience el alma a suspirar por las ollas e Egipto, porque, si sopla el viento de ahí, al momento se hielan las flores y se secan" ${ }^{\prime 19}$.

También hay peligros graves que acechan a los religiosos, para los que Sto. Tomás tiene palabras graves:

"Hete aquí a un religioso: está corriendo bien, y de pronto se le ofrece una oportunidad de salirse del monasterio, y cede: ha caído en la trampa del diablo. Otro, dedicado a repartir las limosnas y a obras de caridad, se prenda de una mujer a la que está ayudando, y cae: ¿qué fue eso sino una cierta lamia? Otro, por reprender a un hermano de su pecado, hace surgir la pelea, la cólera y el mayor de los odios: ¿qué fue eso más que un "barranco" en el camino? Por tanto, hermanos, — se nos dice- andad con cautela, no como necios, sino como prudentes, porque los días son malos (Ef 5,15), es decir, peligrosos." ${ }^{, 20}$

Organizando el discurso y hablando siguiendo un esquema claro, gusta a Sto. Tomas establecer escalas, para dar a entender que lograr la perfección es fruto de un proceso ascendente.

Hace abundantes referencias la vida religiosa y describe la escala que conduce a la perfección, identificando cuatro escalones en la conción 283, dedicada a la Asunción de María. ${ }^{121}$

Referencias a la escala de la perfección se encuentra también en la conción 289, dedicada igualmente a la Asunción de María, que dirige a seglares y reli-

\footnotetext{
${ }^{118}$ Ibid, 3, p. 13.

${ }^{119}$ Ibid, 6, p. 15-17.

${ }^{120}$ Conción 42,4, Dom. Septuagésima, OC, II, 33.

${ }^{121}$ Cfr. Conción 283,3-7, Asunción de María, OC, VII, 431-437.
} 
giosos. Interesante la afirmación de que el ascenso hacia Dios debe partir de la escala del corazón. La dimensión interior es imprescindible para avanzar en ese camino. Su inspiración agustiniana es evidente en este caso.

"Levantar el corazón propio o animar el de otros a las cosas del espíritu, es obra de Dios, sin cuyo auxilio no se consigue. Pon una escala en tu corazón por la que puedas subir hasta Dios. Con ella subes hasta Dios con mayor facilidad y aprovechamiento que por la contemplación de las cosas creadas, porque el alma es imagen de Dios (Gn 1,27), y en ella se ve a Dios mejor que en las otras criaturas. El avance y crecimiento del hombre está en su corazón, no en los ritos externos: serán las virtudes, no las ceremonias, las que te harán crecer, oh hombre. Aunque te hagas monje o sacerdote, obispo o papa, no harás nada de provecho si ese sello exterior no lo llevas en el corazón. Esta escala del corazón se culmina utilizando los tramos de las virtudes, por las que el alma consigue su propio crecimiento y sube hasta Dios."122

En la descripción de esta escala, más elaborada, señala siete peldaños, tomando como base la escena evangélica de Marta y María. Con palabras muy vivas, fruto sin duda de su propia experiencia, describe el gozo de la contemplación:

"¡Feliz aquel que, rompiendo el alabastro, lo derrama todo - no lo destila gota a gota-, cuando el corazón, no pudiendo contenerse por la excesiva fuerza y abundancia del espíritu, se derrama por completo sobre la cabeza de Jesús. Es que no puede soportar aquella sobredosis de deleite, aquella avalancha de gozos y la fuerza del espíritu, y por eso, se eleva y se derrama en un éxtasis. [...] Y ¿qué hacía a los pies de Él? Escuchaba su palabra (Lc 10,39), se nos dice. No intentes que hable tu alma en la contemplación: has venido a escuchar, oh alma, no a hablar. ¿Por qué interrumpes estúpidamente al Señor que te habla? [...] él me habla en mi interior, y mi inteligencia es su lengua con la que me dice lo que quiere. ¡Oh palabra dulce, palabra ardiente! ¡Cómo le gusta este lenguaje a mi alma, cómo la estimula y anima! ${ }^{123}$

Encuentra pistas para definir un itinerario espiritual que incluye los votos en los ocho días transcurridos desde el nacimiento del Señor hasta la circuncisión. La circuncisión es imagen de lo que hay que cortar para lograr el amor de Dios, siguiendo el camino de las virtudes. La circuncisión del Señor aplicada a la vida espiritual de a los religiosos la explica en la conción 241:

"Los ocho días son, pues, las ocho virtudes con las que todo hombre realiza perfectamente la circuncisión. Son éstas: Primera, la pobreza voluntaria, que corta en el hombre la avidez por las riquezas. Segunda, la obediencia,

\footnotetext{
${ }^{122}$ Conción 289,1, Asunción de María, OC, VII, 591.

${ }^{123}$ Conción 289,1-4, Asunción de María, OC, VII, 595-599.
} 
que frena la voluntad sobre sus propios deseos. Tercera, la castidad, que mantiene al cuerpo alejado de los placeres. Cuarta, la abstinencia, que aleja el gusto de los manjares superfluos. Quinta, la humildad, que desliga al alma de los deseos vanos de honores y pompas. Sexta, la mansedumbre, que frena el apetito irascible frente a los movimientos de ira y a los rencores. Séptima, el silencio, que cohíbe la lengua de la parlería. Octava, la moderación, que de forma general pone mesura en todos los actos y gestos, para que en nada haya exceso, y por eso se llama moderación. Acabados estos ocho días, mejor aún, cuando el hombre haya sido perfeccionado a través de ellos, entonces ya está apto para la circuncisión, que lleva a término un cuchillo de pedernal, es decir, el amor de Dios. [...] El amor de Cristo es el cuchillo; él es quien circuncida al hombre de modo perfecto en todo; además, fácilmente: el que ama de modo perfecto a Dios, lo desprecia todo teniéndolo por nada. Al que ama a Dios, le sobra todo el mundo. ¿Qué hizo a los anacoretas estar tan circuncidados que, dejándolo todo, vivían solitarios en el yermo, con muy escaso alimento? El amor de Dios, porque, sin él, es imposible que se dé una verdadera circuncisión." 124

En varios sermones presenta otras escalas para llegar a Dios, no limitado a religiosos, sino también a seglares. ${ }^{125}$ Las bienaventuranzas, por ejemplo, constituyen la escala por donde subieron los santos para alcanzar la perfección.

"Si nos gusta el premio, que no nos asuste el esfuerzo. Si nos atrae la corona, que no nos aterre la lucha. ¿Quieres llegar hasta donde llegaron los santos? Sube por donde ellos subieron [...] Bienaventurados los pobres de espiritu... Bienaventurados los mansos... Bienaventurados los que lloran, etc. Ahí tienes la escala por la que subieron los santos al cielo; es corta, sube tú por ella." 126

Llegar a la cima del monte de las bienaventuranzas requiere subir los siete tramos que dan contenido a las bienaventuranzas. Algo imposible de hacer con las propias fuerzas.

"Que nadie piense que puede escalar tan elevadas alturas por sus propias fuerzas, porque el hombre no triunfa por su fuerza $(1 \mathrm{Sm} 2,9)$, ni santo alguno ha subido por su propio esfuerzo. [...] todo el que desea ver al Señor en la cúspide de la majestad y subir al mismísimo monte elevado de Sión, en primer lugar, huya de la turbamulta de aficiones y deseos terrenales, despréndase de los bienes temporales y pase por encima de todo:

\footnotetext{
${ }^{124}$ Conción 241, Circuncisión del Señor, OC, VI, 295,297.

${ }^{125}$ Cfr. Conción 217, Dom. XVIII después de Pentecostés, OC, V, 353; Conción 406, Ascensión del Señor, sermón segundo, $O C$, IX, 109.

${ }^{126}$ Conción 361,6, Todos los santos, OC, VIII/2-3, 581.
} 
evite las preocupaciones, rehúya los asuntos mundanales, aléjese de toda inquietud."127

El último estadio del camino ascendente es la contemplación y el gozo de Dios:

"Con esto, llega la última etapa, la auténtica paz del corazón, y el sosiego. Ya no molesta el temor, no punzan ya los hechizos, ni tienta el placer, ni incita la pasión; no hace perder la calma la adversidad, ni acoquina la turbación; guarda silencio la carne, callan los sentidos, calla el mundo, callan todos los fantasmas, calla el instinto, no se oye el estrépito de los deseos, mantienen la calma los movimientos desenfrenados. El mundo entero está muerto para el alma. Se hizo silencio en el cielo (Ap 8,1), es decir, en el corazón celestial. Solo Dios es amado, solo él es deseado, solo él es esperado, solo él es buscado." 128

Dedica un breve tratado a los cuatro pasos necesarios para llegar a la contemplación, inspirándose en la Scala paradisi, c, 2 de Juan Clímaco: comenzar con la lección, meditar lo leído, orar sobre lo meditado y alcanzar la contemplación. Con la contemplación el alma es sustentada y mantenida con gran delectación. ${ }^{129}$

La contemplación es una meta en la vida consagrada y así se lo expone el santo:

“...ahora leáis, ahora oréis, ahora cantéis en el coro, ahora os estéis en vuestras celdas rumiando y pensando en alguna cosa espiritual, esto sólo haced, esto sólo buscad, esto sólo procurad: que gustéis y que gustando veáis cuán suave es el Señor. [...] ¡Cuán manifiesto y cuán experimentado es esto a los varones religiosos, amadores de la soledad y que acostumbran a darse a los ejercicios espirituales! ¿Qué todo el deleite del mundo y su alegría comparada al que el religioso allá encerrad o en su celda con su Dios? [...] Dame una religiosa en la cual more el espíritu del Señor, [f.536v] ¡cuán viva, cuán ferviente, cuán alegre, cuán despierta, cuán ligera, cuán consolada, cuán aparejada está para todo bien!" ${ }^{130}$

El sueño de los sentidos es propio de la vida religiosa:

"El Señor cura cauterizando, cuando la herida es una fístula molesta. [...] Por último, cura mediante el sueño, cuando cierra los sentidos y las apeten-

\footnotetext{
${ }^{127}$ Conción 359, Todos los santos, OC, VIII2/3, 545.

${ }^{128}$ Ibid, 555.

${ }^{129}$ De la lección, meditación, oración, contemplación [tratado], OC, X, 169.

${ }^{130}$ Conción 118,3-5, Viernes III Cuaresma, OC, III, 307-313.
} 
cias de cosas temporales y hace que el pecador se duerma en la contemplación de los bienes eternos. Dice a propósito el Cantar: Yo duermo y mi corazón está en vela (Cant 5,2).

Así duermen sin cesar los religiosos; así deben dormir temporalmente los seglares y, si no están siempre dormidos para el mundo como los religiosos, al menos los días festivos, y en ellos que estén libres para Dios." ${ }^{131}$

El ocio es imprescindible para profundizar en el conocimiento de la Sagrada Escritura y gozar de la contemplación:

"Todo el que quiera encontrarse con el tesoro [de la Sagrada Escritura] que adquiera el campo, es decir, el ocio, dejándolo todo, porque la sabiduría la conseguimos en el ocio, y el alma se hace sabia en el sosiego, pues es como el agua clara y quieta, que refleja maravillosamente las imágenes; en cambio, si se la remueve, no se ve nada en ella. El alma serena es un magnífico espejo." ${ }^{132}$

Sto. Tomás de Villanueva fue un contemplativo. Al comunicar a sus fieles su experiencia espiritual, cómo se encontró sumido en la contemplación y el gozo, parece describir un fenómeno místico. Lo hizo comentando la experiencia de Pedro, Santiago y Juan en la transfiguración, y sintiéndose identificado con ellos en el gozo místico de la contemplación:

"en lo que se refiere a mí, hermanos, (por hablaros un poquito y de pasada de mi indigna persona), cuando alguna vez, y esto muy en raras ocasiones, no por mis méritos, sino por una dádiva gratuita del bueno por excelencia, Cristo, se me ha concedido - repito- subir con él a un monte alto, y allí contemplar, aunque fuera por un instante y de lejos, la gloria de su rostro, con qué clamores y lágrimas suplico insistentemente: «Señor mío, iqué bueno es estar los dos aquí! no consientas que baje yo jamás de este monte. Tengo suficiente con este gozo, me basta esta presencia tuya. No te vayas, no te marches de mi lado, por favor. Que pase yo así toda mi vida, que gaste en esto todos mis días. ¿Para qué buscar otra cosa? Sólo esto quiero, sólo esto deseo, sólo es ansío, sólo por esto suspiro...» pero, ¡ay, ay! rápidamente se desvanece aquella gloria, aquella paz, aquella dulzura, y yo me quedo lleno de nostalgia. Deja de pronto al alma en añoranzas, y, como un relámpago que no se detiene, así pasa su claridad. ¡Oh si se hubiera eternizado!”133.

En el proceso de canonización son varios los testigos, religiosos agustinos y de otras órdenes, sacerdotes y seglares, que afirman que Sto. Tomás fue un contempla-

\footnotetext{
${ }^{131}$ Conción 330, San Lucas, OC, VIII/2-3, 91,93.

${ }^{132}$ Conción 374,3, Para la fiesta de una virgen, $O C$. VIII/2-3, 765.

${ }^{133}$ Conción 94,8, Dom. II Cuaresma, OC, II, 751,753.
} 
tivo y que experimentó fenómenos místicos, cayendo en arrobamiento mientras oraba, recitaba el oficio divino, celebraba la misa e incluso predicaba ${ }^{134}$.

A juicio de Allison Peers, Sto. Tomás fue el único autor y predicador del $\mathrm{s}$. XVI que habló desde el púlpito de la vida mística ${ }^{135}$, no sólo como experiencia propia, sino como resultado del desposorio espiritual del alma con Dios, cuando ésta "es arrebatada fuera de sí y embriagada con el vino fuerte de la caridad".

La contemplación es necesaria en la vida espiritual, aunque puede predominar la acción donde la contemplación resulte más difícil:

"[...] Y por eso si vieres que no tenéis ánima o espíritu para subir al monte de la contemplación, ejercitaos en el valle, en lo bajo, y allá os podéis quedar y andar en la vida activa, que es también buena, aunque vale poco sin la otra; y por eso ejercitaros habéis lo mejor que pudiereis en la contemplación, aunque sea poco, porque sin ésta no haríais nada ni os podríais ejercitar en la activa;...."136

La contemplación es ejercicio obligado del religioso y advierte al novicio que va a tomar hábito que se actúe con prudencia, no siendo que pretendiendo vida más alta, abandone la vida activa y pierda ambas ${ }^{137}$

El camino de la perfección requiere la perseverancia:

"Para crecer en la virtud y en la perfección hace falta la perseverancia, lo mismo que pasa con la sabiduría. No midas cada día lo que avanzas, mídelo al cabo de un año. Desdichados de aquellos que perdieron la constancia y que, desesperados de avanzar en la virtud, se entregaron a toda clase de bajezas, de inmundicias y de placeres mundanos." ${ }^{138}$

Y encuentra estímulo en la imitación de los santos, porque “... los hechos tienen más fuerza y eficacia que las palabras, y mueve más una vida santa que una lengua expedita." 139

\footnotetext{
${ }^{134}$ Summarium omnium positionum quae propositae fuerunt in causa Canonizationis Venerabilis Viri fratris Thomae a Villanueva, ex ordine Heremitarum sancti Augustini, Archiepiscopi Valentini, tam super Virtutibus piisque operibus, quam miraculis eiusdem, et approbatae a Reverendissimis Dominis Auditoribus Rotae, Iudicibus apostolicis praedictae illius Canonizationis, ut constat ex Registro omnium Congregationum in dicta causa celebraturarum. $\mathrm{N}^{\circ}$ 5: DE RAPTIBUS ET EXTASIBUS SERVI DEI FRATRIS THOMAE [transcripción de Laureano MANRQUE, OSA]

${ }^{135}$ Studies of the Spanish Mystics, London 1930, II pp, 77-96, citado por Argimiro TURRADO, Santo Tomás de Villanueva, maestro..., 58, nt. 129.

${ }_{136}$ Cfr. Opúsculos ascético-místicos, Plática y aviso al religioso..., OC, X, 213.

${ }^{137}$ Opúsculos ascético-místicos, Plática y aviso al religioso..., OC, X, 214.

${ }^{138}$ Conción 47,7, Dom. Sexagésima, OC, II, 125.

${ }^{139}$ Conción 300,7, San Andrés, apóstol, OC, VIII/1, 131.
} 


\section{SANTO TOMÁS FRENTE A LOS ATAQUES DEL PROTESTANTISMO A LA VIDA MONÁSTICA}

Sto. Tomás conoció en su tiempo las convulsiones que afectaron a Europa, creando una situación crítica por la inestabilidad política y la división religiosa.

Flagelos de su tiempo eran la amenaza turca a Europa y la división de la Cristiandad provocada por la reforma protestante. Era muy consciente de que constituían las dos grandes amenazas de la Europa cristiana.

"Por de pronto, sabed que el Anticristo será el azote de Dios, que el turco lo está siendo, y que en nuestros días el miserable Lutero es también un azote. . ¡Ojalá que Dios no nos eche fuera de su templo con estos flagelos! Quiera Dios que no se cumpla en nosotros la amenaza que el Señor hizo por su Profeta: He de echarlos de mi casa por causa de sus perversas obras. Nunca más los amaré $($ Os 9,15$)$." ${ }^{\prime 140}$

En la conción 180, predicando en las Rogativas, hace una descripción terrible de la persecución que está sufriendo la Iglesia, derribando iglesias y monasterios, violando vírgenes, asesinando sacerdotes, despedazando monjes.

“¿Y tú, Señor, duermes? ¿Y tú permaneces callado? ¿No te importan esos desmanes? ¿Te trae sin cuidado que perezcamos? ¿Qué puedo decir, Señor, qué puedo decir yo? ¡Ay! Estoy desconcertado todo el día y doy voces llamando, y no hay nadie que me salve. Porque, ¿cuántas barbaridades no hizo este turco en aquella toma de Constantinopla?"141

La persecución turca constituye una experiencia inédita para la Iglesia:

"desde hace mil doscientos años hasta hoy, es decir, desde tiempos del emperador Constantino, la Iglesia nunca ha padecido una calamidad tan grande" 142

Por otra parte, Sto. Tomás conocía muy bien el desbarajuste introducido en la vida religiosa con el protestantismo, que afectó muy gravemente a la Iglesia y a la propia orden de San Agustín. Sus juicios sobre las demasías de Lutero y la reprobación de los votos y otras prácticas ascéticas llevan a Santo Tomás a expresiones de gran dureza y a anunciar que se ha abierto para estos reformadores el camino del infierno.

Su descripción sobre el daño que ha hecho Lutero a la vida religiosa es muy

\footnotetext{
${ }^{140}$ Conción 131, Lunes IV Semana Cuaresma, OC, III, 439

${ }^{141}$ Conción 180,4-6, Rogativas, OC., IV, 377.

${ }^{142}$ Conción 87, Jueves I de Cuaresma, OC, II, 657.
} 
viva y apremiante en una conción pronunciada con motivo de la fiesta de S. Agustín. Denuncia los abusos introducidos por la rebelión protestante con pasión, lleno de celo por la casa de Dios:

"Han llegado aquellos tiempos peligrosos, sobre los que nos previene el oráculo evangélico: Aparecerán — dice—falsos profetas, [etc.]. ¡Clarísima profecía para nuestros tiempos! ¿Qué otra cosa dicen los actuales herejes sino aquí está el Cristo, allí está el Cristo? Cristo no está - dicen ellos- en las leyes canónicas, ni en los sacramentos de la Iglesia, ni en las distintas observancias de las Órdenes religiosas, ni en la liturgia sagrada de las misas, ni en las ceremonias exteriores del culto divino, ni en el rezo asiduo de las Horas, ni en las comidas sin carne, ni finalmente en esta regla de vida eclesiástica que desde tiempos de los apóstoles hasta hoy se mantiene en la Iglesia, en toda la tierra y en todos los países donde hay creyentes.

Pero, míralo aquí, míralo allí, dice Lutero. Míralo aquí, míralo allí, dice Ecolampadio. Cada cual establece a su antojo para los fieles de Cristo su propia forma de vida para que la sigan; y no se ponen de acuerdo unos con otros, sino que uno dice una cosa, otro dice otra. ¿Cómo van a coincidir entre sí quienes discrepan de la Verdad? Desdichados alemanes, ¿quién os fascinó para que desobedecierais a la Verdad? (Gal 3,1). ¿Quién engañó tan taimada e irracionalmente a una gente noble, ortodoxa desde el principio? ¡Que un hombrecillo de esa talla os haya apartado de las enseñanzas antiquísimas de los santos Padres y de la fe ortodoxa de la Iglesia y de una reputadísima norma de vida! Entrad de nuevo en vosotros mismos, os lo ruego (Is 46,8), porque no es posible que la Iglesia de Dios esté sometida al error, la Iglesia que es guiada por el Espíritu Santo, organizada por Cristo y honrada por una incontable multitud de santos. ¿Preferís arder con Lutero a reinar con Agustín, con Ambrosio, Jerónimo, Gregorio, Bernardo y otros, cuyos nombres sin duda están insertos en el libro de la vida? (Flp 4,3) [...] Si predicáis a Cristo, escuchad a Cristo: él mismo dice que no está aquí o allí, es decir, en un conciliábulo privado de herejes, sino en el común acuerdo de la Iglesia católica ¿Y vosotros dejáis de lado, con desprecio, a la Iglesia católica y la fe por todos compartida? ¿Andáis en busca de rincones y encrucijadas? Lutero casa a los monjes, invita a los sacerdotes a casarse. ¡Cuidado!, por favor, no le creáis, ya había predicho el Señor que sucedería eso, no lo sigáis. [...] Estad precavidos, vosotros, los que estáis en el terrado de la perfección, es decir, los rectores y maestros de la Iglesia de Dios, los que desde las alturas de la perfección hacéis sonar a diario como trompetas ante el pueblo llano la palabra de Dios y la doctrina de la salvación [...] Mirad también por vosotros, hombres religiosos, que sudáis día y noche sin cesar en el campo del Señor, y con la palabra de salvación lo sembráis: porque aquellos corruptores - lo sé- intentarán convenceros en aquella hora, bajo el nombre de Cristo, de que abandonéis la religión, de que hagáis de menos el celibato, de que os caséis, de que os impliquéis en la cosas del siglo, no bajéis del terrado a coger 
las cosas temporales que un día abandonasteis; no volváis atrás, a la vida del siglo que, al llamaros Dios, dejasteis. [...] Así de clara es la proclama contra los herejes. ¡Ojalá Dios les abra los ojos para que vean y se arrepientan de tamaña locura." 143

A lo largo de las conciones, Lutero es citado cerca de veinte veces, en términos siempre de gran rigor por la división introducida en la Iglesia. No hay en el santo arzobispo resquicio o concesión alguna a un cierto irenismo que le lleve a comprender o justificar la ruptura luterana. La contemporaneidad con la ruptura y el celo pastoral le hacen particularmente agresivo en el lenguaje, llevándole a la inclusión de Lutero entre los condenados en el juicio final:

"Allí estará presente Judas en compañía de todos los traidores y sicarios; allí Caín con los matones homicidas; Nerón con los tiranos sin entrañas; Herodes con los parricidas; Pilato con los jueces injustos; Mahoma con los insensatos; Arrio y Lutero con los herejes; Simón con los magos y simoniacos; Nino con los paganos; Sardanápalo con los sinvergüenzas voluptuosos: todos atados en haces y reunidos para el fuego, según la parábola evangélica de la cizaña (Mt 13,25ss). Todos esos serán llamados a la izquierda, como cabritos desvergonzados y revoltosos."

En varias conciones se ocupa directamente de la revolución introducida por los reformadores protestantes en la vida religiosa, de su ataque a los votos y a la disciplina monástica.

Contra Lutero esgrime Sto. Tomás el aforismo de Cipriano:

“... así como fuera del arca nadie se salvó del diluvio, sino que todos perecieron, lo mismo fuera de la Iglesia no hay salvación. Que lo escuchen los herejes, que lo oiga Lutero. Atiende, Lutero: no te digo otra cosa, no echo mano en contra tuya de otro argumento distinto del que utiliza Agustín contra Donato: Mira bien dónde te encuentras. ¿No es verdad que estás fuera de la Iglesia? Sábete que fuera de la Iglesia no hay salvación. Estás en medio de diluvios, vas a perecer." 145

Así se pronunciaba sobre los desmanes del protestantismo en una conción en la fiesta de San Agustín:

"Ahora bien, lo mismo que intentaba entonces [el demonio] aconsejar a Cristo, lo pretende hoy por medio de sus satélites con los prelados de la Igle-

\footnotetext{
${ }^{143}$ Conción 294,1, S, Agustín, nuestro Padre, OC, VIII/1, 49-53.

${ }^{144}$ Conción 2, Dom I Adviento (sobre Juicio final), OC, I, 43.

${ }^{145}$ Conción 298, Sta Ana, OC, VIII/1, 95. Mismas frases, casi textuales, en Conción 337, S. Matías, VIII/2, 233.
} 
sia, a saber: que conviertan en pan, es decir, en placer, las piedras de la penitencia y de la austeridad. Por eso intentan echar por tierra la confesión auricular instituida por Cristo, las asperezas de la vida religiosa, el celibato de los clérigos, la abstinencia de carne, el rigor de los ayunos, y llevar a la Iglesia de Dios a una vida placentera y carnal.,"146

Naturalmente Sto. Tomás no lamenta solo los efectos del protestantismo sobre la vida religiosa, sino sobre toda la Iglesia en general. Se trata de uno de los peligros devastadores de la Cristiandad, al que se suma la mencionada presión de los turcos sobre Europa. La situación de riesgo le mueve a explicitar cómo predicar para defender la fe frente a la herejía, como recogíamos en el apartado octavo:

"Mas cuando se toque a rebato y se trate de la defensa de la fe contra los herejes, entonces el sermón será largo pero conciso, elocuente, ingenioso, juicioso, elegante, adornado, eficaz, poderoso y fuerte. Asimismo, cuando el pueblo deba ser corregido de sus pecados, entonces resuene la trompeta con más fuerza."147

La situación política y religiosa que le tocó vivir hace que su visión del mundo sea bastante catastrofista. Pero quiere sacar una conclusión positiva de tanto mal: si estando como están las cosas amamos tanto el mundo, si todo fuera gozoso y positivo el olvido de la vida eterna sería total.

"nuestra madre la Iglesia está experimentando un grave dolor por esta mezcolanza y enfrentamiento entre malos y buenos. Cual otra Rebeca, que en tiempos pasados tuvo que sufrir un grandísimo sofoco por la lucha que en su seno tenían entablada sus dos hijos que le rasgaban las entrañas con sus peleas (Gn 25,23), así la Iglesia, siente por esta guerra intestina más dolor que por la guerra exterior de los paganos, porque ésta tiene lugar dentro, porque no se acaba nunca y porque es universal. [...] En este mundo todo se vuelve peleas, guerras y discordias; no hay paz, no hay seguridad ninguna, porque vivimos entre víboras y alacranes y a la fuerza tenemos que soportar sus mordeduras; y esto nos viene bien para que al menos así deseemos aquella patria celestial. Porque si, estando como está todo lleno de males, de sobresaltos y penalidades, amamos tanto esta vida, ¿qué sería si fuera pacífica, tranquila y placentera? ¿Quién suspiraría por el cielo? ¿Quién menospreciaría la vida? Los males que aquí nos aprietan, como decía Gregorio, nos impulsan a ir hacia Dios." ${ }^{148}$

\footnotetext{
${ }^{146}$ Conción 73, Dom. I Cuaresma, OC, II, 429, 431.

${ }^{147}$ Comentario de varios capítulos del libro de los Números, $O C, \mathrm{X}, 7$.

${ }^{148}$ Conción 337,3-5, San Matías, OC, VIII/2-3, 237.
} 


\section{LA REFORMA DE LA VIDA RELIGIOSA PROPICIADA POR EL CONCILIO DE TRENTO}

El concilio de Trento trató sobre los religiosos y monjas en la sesión XXV, celebrada en los días 3 y 4 de diciembre de 1563. Sto. Tomás había fallecido en 1555 , es decir, ocho años antes. Pero es interesante constatar la sintonía existente entre la predicación de Sto. Tomás sobre la vida consagrada y la normativa promulgada años después por el concilio. La seguridad de su enseñanza, acorde siempre con la doctrina de la Iglesia, frente a los ataques sufridos por los reformadores, hace que el santo arzobispo de Valencia tenga un puesto destacado en la historia de la Iglesia. Esta seguridad de su magisterio resulta evidente en la defensa del valor de la vida consagrada y de los principios evangélicos y bíblicos en que se inspira, en total sintonía con lo proclamado años después por el concilio de Trento.

Quiso el concilio la vuelta al rigor de la regla, la negación de cualquier propiedad personal por parte de los religiosos, aunque se permitía a las provincias y casas (excepto en el caso de aquellas órdenes que por su propia normativa rechazaban cualquier tipo de propiedad, sobre todo de la familia franciscana); que los religiosos vivan en la comunidad, incluidos los dedicados a la universidad; que se restablezca y observe la clausura, particularmente en los conventos de mujeres, encomendando su vigilancia a los obispos.

El concilio dio normas sobre las elecciones de superiores y las condiciones que deben revestir los elegidos, sobre la dirección de los monasterios que no tienen visitadores ordinarios. Puso bajo los ordinarios a los monasterios dependientes de la Santa Sede. Determinó prácticas sacramentales que deben seguirse en los conventos (particularmente eucaristía y reconciliación), obligó a los regulares a observar determinadas normas pastorales diocesanas, entre otras que los regulares exentos participen en las procesiones públicas, excepto los que tienen en sus leyes la clausura estricta. Establece cómo castigar al regular exento que delinque, la obligatoriedad del noviciado y la edad mínima para la admisión a los votos, así como otras particularidades sobre diversos temas. Castiga con la excomunión a quien fuerce a entrar en religión a un candidato, establece cómo proceder en caso de nulidad de profesión, determina la obligación de los superiores de visitar los conventos bajo su jurisdicción. También que los superiores sean de la misma orden. Finalmente declara la obligatoriedad de las normas proclamadas por el concilio sobre regulares ${ }^{149}$.

\footnotetext{
${ }^{149}$ Texto del decreto sobre los religiosos y las monjas: http://www.conoze.com/doc.php?doc=5312
} 
Estas normas del concilio están perfectamente en sintonía con el pensamiento de santo Tomás, quien se anticipó a su proclamación.

\section{LA DEVOCIÓN A MARÍA}

Santo Tomás de Villanueva fue muy devoto de María. La Virgen está muy presente en sus conciones, como faro que ilumina toda la vida cristiana. Es un modelo de perfección para todos los fieles y, de modo especial, para los religiosos, a quienes propone explícitamente la imitación de María

Predicando sobre la visitación de María a Sta. Isabel dice a las monjas:

"Seguid también vosotras, oh vírgenes, el ejemplo de esta Virgen, y subid tras ella, con paso ligero, la montaña de las virtudes. Sobrevolad las cumbres de la perfección y traspasar las escarpadas lomas de la doctrina evangélica, pues sabéis perfectamente que para eso estáis donde estáis y que en eso mismo estáis seriamente empeñadas desde el primer momento de vuestra entrada en religión" $" 150$.

Pero, al mismo tiempo que anima a las vírgenes a subir con María a la cumbre de las virtudes, les pide paciencia, decisión y humildad.

"Seguid humildes a la humilde, con modestia a la que es modesta, y a la que lleva dentro a Cristo acompañadla llenas también de Cristo, porque no puede correr hacia las altura la que no lleva con ella a Cristo. María camina con presteza hacia la región de la montaña, metiéndole prisa el fruto que lleva dentro; no hay duda que vosotras correréis también gozosas si habéis metido a Cristo en el seno de vuestros pensamientos, si lo lleváis en el corazón. Llevar a Cristo dentro no supone una carga, sino un alivio: no sobrecarga al alma que lo lleva, sino que la aligera." 151

Dirá también a las vírgenes que sigan con gozo al Cordero:

"id corriendo a la montaña, subid detrás de María [...] Esto es lo que ahora os tengo que decir imitadla, seguidla. Teniéndola a ella de guía y maestra, avanzaréis con rapidez y llegaréis felizmente a vuestro destino último, es decir ala perpetua e inmarcesible corona de la gloria $(1 \mathrm{Pe} 5,4)$ la cual tenga a bien concederos el Señor de las virtudes y Rey de la gloria (Sal 23,10), al cual con el Padre y el Espíritu Santo sean dados el honor y la gloria por los siglos de los siglos Amén" 152

María es la precursora de la vida consagrada:

"Por esto tú, oh Virgen, tú tienes la primacía entre las vírgenes, tú eres la primera guía y maestra de las vírgenes, tú el prototipo de toda virginidad, tú

\footnotetext{
${ }^{150}$ Conción 279.7, Visitación B Virgen María, OC, VII, 325.

${ }^{151}$ Conción 279,10, Visitación B Virgen María OC, VII, 331

152 Ibid, 333.
} 
la inspiradora e iniciadora de la virginidad, la fundadora primera de esta santa religión. ¡Oh vírgenes, qué magnífica maestra tenéis! No fue san Agustín, ni san Benito, no fue Francisco, ni Domingo, ni ningún otro de los santos Padres, el inspirador de esta vida de santidad, sino que fue la santa Virgen, Madre de Dios, la primera en dar con este camino, y ella se lo enseñó a los hijos de Adán. Ella fue la primera que enseñó el celibato a los hombres, ella les enseñó a llevar una vida angélica en carne humana y a emular la pureza de los espíritus celestiales. Ella fue la primera en consagrar a Dios su virginidad, ella estimuló a otros con su ejemplo a que hicieran esto mismo,"153

Sólo en la Virgen se dio la perfección completa:

"aunque todos los santos se esforzaron cuanto pudieron por asemejarse a Cristo y en reproducirlo e imitarlo - ya que en esto consiste nuestra perfección - ninguno sin embargo lo consiguió del todo, sino sólo en parte, uno en la humildad, otro en la castidad, otro en la mansedumbre. Tan sólo la Virgen lo imitó en todo, siendo un vivo retrato de sus gracias y virtudes, aunque el brillo de las mismas fuera más perfecto en el Hijo por su unión con la divinidad." 154

María es toda ella y en todos los aspectos, virgen: virgen en la carne, virgen en su mente, virgen en la mirada, virgen en el tacto, virgen en sus pensamientos, virgen en sus afectos, virgen en sus palabras, virgen en sus actos, virgen en el espíritu, virgen en los sentimientos, virgen perfectísima, virgen incontaminada: sin tacha en su cuerpo, sin tacha en su alma, sin tacha en su pensamiento, limpia no sólo de la sensualidad, sino también de cualquier mota de pecado y de cualquier salpicadura de los vicios. Santa, pura e inmaculada la Virgen." ${ }^{155}$

\section{CONCLUSIÓN}

Nos hemos acercado a la figura del santo obispo Tomás de Villanueva para conocer su pensamiento y planteamientos pastorales sobre la vida consagrada, identificada en su tiempo con religiosos y monjas. Él mismo fue un religioso ejemplar, que se mantuvo fiel a su opción religiosa, no sólo durante los 28 años en que vivió en la orden de San Agustín, sino también en los más de 10 años en que fue arzobispo de Valencia.

Los autores espirituales de cualquier época han sido siempre críticos frente a la realidad contemporánea de la sociedad y la Iglesia, como fruto de su propia autoexigencia de vida. Sto. Tomás no fue una excepción, por lo que valora críticamente su propio entorno, denunciando a los obispos, clérigos, religiosos y

\footnotetext{
${ }^{153}$ Conción 272,6, Anunciación, OC, VII, 287. Las mismas ideas en Conción 267,6, Natividad de María, $O C$, VII, 105.

${ }^{154}$ Conción 268,4, Natividad de María, OC, VII, 131.

${ }^{155}$ Conción 272,6, Anunciación, $O C$, VII, 187, 189.
} 
responsables civiles de cualquier grado o condición que no viven de modo acorde con la moral o la disciplina. Sus abusos constituyen un peligro para quienes quieren seguir en simplicidad y fidelidad al Señor. Por eso les previene de los peligros y les marca el camino.

Fue muy consciente de la división introducida por el protestantismo en la Iglesia y la deletérea labor emprendida contra la vida consagrada, la fe y la disciplina eclesial. En este tema manifiesta particular preocupación, mostrándose muy crítico frente a los herejes, sobre todo Lutero.

La época en que tocó vivir a Sto. Tomás estaba llena de peligros para los consagrados. A ellos alienta a no dejarse perder por quienes están destruyendo los principios de la vida consagrada.

Como pastor de la Iglesia supo valorar los diversos carismas suscitados por el Espíritu, prestándoles particular atención y fomentándolos desde su responsabilidad eclesial. Aunque son pocas las conciones dirigidas específicamente a los religiosos, son muchas las alusiones a su estilo de vida en su predicación, de modo que las citas sobre la vida consagrada constituyen una valiosa antología de orientaciones espirituales dirigidas a los religiosos.

La vida comunitaria tiene un papel preponderante pues la disciplina monástica está encaminada a vivir en armonía, dedicados al cumplimiento de la regla, centrados en la oración y en el servicio comunitario.

Horizonte de la vida religiosa es la unión con Cristo, a la que hay que hay que llegar subiendo la escala de la perfección y alcanzando la contemplación. Volver a Cristo era la aspiración reformista tanto los que emprendieron el camino de la herejía como los que la pretendían en el seno de la ortodoxia.

La Sagrada Escritura, como Palabra de Dios, bien conocida y meditada por Sto. Tomás, ilumina el camino de la renovación. En el deseo de volver a las fuentes se acerca también a los santos Padres, que estudia y conoce, sobre todo S. Agustín.

En el seguimiento de Cristo, nos ayudan los ejemplos de los santos, particularmente de los fundadores. Juan el Bautista fue precursor también en el estilo de vida consagrada, pero el ejemplo más preeminente es, sin duda, la Virgen María.

La doctrina de Sto. Tomás en lo referente a la vida religiosa es doctrina segura, estimulante y presentada con fuerza y originalidad, aunque no presenta novedades, sino que pide fidelidad. Fue doctor no innovando, sino sosteniendo y defendiendo la doctrina frente a la desintegración que experimentaba la vida religiosa en Europa, como fruto de los ataques y principios de los reformadores protestantes. Su doctrina, en todo conforme con la fe de la Iglesia proclamada en Trento, constituye un manual válido en nuestros días para el seguimiento de Jesucristo a través de la consagración religiosa. 
Como dice Antonio Cañizares, la doctrina y praxis pastoral de Sto. Tomás de Villanueva "encierra un valor innegable, que trasciende su momento histórico concreto [...] su proximidad y su perenne actualidad se debe, sin duda alguna, al hecho de que es un auténtico testigo de Cristo entre los hombres, un verdadero profeta por el que Dios habla a su Iglesia, caminante hacia la plenitud [...] Religioso agustino marca pautas por las que debieran moverse los pasos de la renovación en profundidad de las órdenes religiosas." 156

${ }^{156}$ Antonio CAÑIZARES, Sto. Tomás de Villanueva ..., 243. 